\title{
DOCTRINA DEL TRIBUNAL CONSTITUCIONAL DURANTE EL PRIMER CUATRIMESTRE DE 2019
}

Doctrine of the Constitutional Court during the first four-month period of 2019

\author{
JUAN CARLOS DUQUE VILLANUEVA \\ Tribunal Constitucional \\ duque@tribunalconstitucional.es \\ CARLOS ORTEGA CARBALLO \\ Tribunal de Cuentas \\ carlos.ortega@tcu.es.es \\ HERMINIO LOSADA GONZÁLEZ \\ Tribunal Constitucional \\ losada@tribunalconstitucional.es \\ TOMÁS DE LA QUADRA-SALCEDO JANINI \\ Universidad Autónoma de Madrid \\ tomas.quadra@uam.es
}

Cómo citar/Citation

Duque Villanueva, J. C., Ortega Carballo, C.,

Losada González, H. y De la Quadra-Salcedo Janini, T. (2019).

Doctrina del Tribunal Constitucional durante el primer cuatrimestre de 2019.

Revista Española de Derecho Constitucional, 116, 221-266.

doi: https://doi.org/10.18042/cepc/redc.116.08 
I. JURISDICCIÓN CONSTITUCIONAL. DERECHO PROCESAL CONSTITUCIONAL. II. FUENTES DEL DERECHO. III. ORGANIZACIÓN TERRITORIAL DEL ESTADO. IV. ORGANIZACIÓN DE LOS PODERES PÚBLICOS. V. DERECHOS FUNDAMENTALES.

\section{JURISDICCIÓN CONSTITUCIONAL. DERECHO PROCESAL CONSTITUCIONAL}

1. Escasa novedad presentan las resoluciones dictadas por el TC durante este cuatrimestre en lo que a este apartado de la crónica se refiere.

En relación con los recursos de inconstitucionalidad se reitera en la STC 5/2019 (Pleno), de 17 de enero', la legitimación de la presidenta del Gobierno en funciones para su interposición, pues, como ya se dijo en la STC 97/2018, de 19 de septiembre (FJ 2), «la Constitución no excluye, siquiera sea explícitamente, la legitimación del Presidente del Gobierno en funciones para interponer el recurso de inconstitucionalidad» (FJ 2).

Por lo que atañe al acuerdo previo de la voluntad de los miembros de las cámaras de promover un recurso de inconstitucionalidad, en la STC 14/2019 (Pleno), de 31 de enero, se recuerda que no es un requisito subsanable la falta de adopción de dicho acuerdo dentro del plazo legalmente previsto para interponer el recurso, pero sí su falta de acreditación en el referido plazo [FJ 2 a)].

2. En el ATC 27/2019 (Pleno), de 9 de abril, se inadmite a trámite una cuestión de inconstitucionalidad promovida contra determinados preceptos de una ley autonómica por su falta de aplicabilidad como consecuencia de la cláusula de prevalencia del art. $149.3 \mathrm{CE}$. Tras apreciar que en el auto de planteamiento el órgano judicial exterioriza «el imprescindible juicio de aplicabilidad y relevancia de acuerdo con lo previsto en el art. 35 LOTC» (FJ 2), el TC, con base en la doctrina sobre el alcance de la cláusula de prevalencia sentada en las SSTC 102/2016, de 25 de mayo, 116/2016, de 20 de junio, y 240/2016, de 1 de diciembre, insiste en que en los supuestos en los que la ley autonómica incurre en una inconstitucionalidad sobrevenida al haber modificado el legislador estatal en el ejercicio de sus competencias las normas básicas sin que el legislador autonómico haya procedido a adaptar su normativa a las nuevas

$1 \quad$ Véase infra p. 238. 
bases «no resulta necesaria la declaración de inconstitucionalidad de la ley autonómica, sino que cabe su mera inaplicación, por haber sido desplazada por la norma estatal al amparo de la cláusula de prevalencia del art. 149.3 CE» $(\mathrm{FJ} 4)^{2}$.

3. A las cuestiones prejudiciales de validez de las normas forales fiscales les es de aplicación, dada la similitud que existe entre ambos procesos constitucionales, la doctrina constitucional sobre el juicio de relevancia de las cuestiones de inconstitucionalidad y, en particular, sobre el control externo y formal que corresponde al TC en relación con el juicio de relevancia exteriorizado por los órganos judiciales en los autos de planteamiento. De acuerdo con dicha doctrina, el TC desestima en la STC 8/2019 (Pleno), de 17 de enero $^{3}$, el óbice de admisibilidad de la falta del juicio de relevancia de una cuestión prejudicial, ya que entiende que el órgano judicial había argumentado suficientemente la aplicabilidad y relevancia de la norma cuestionada, razonando «acerca del nexo causal» existente entre su validez y la decisión a adoptar en el proceso a quo (FJ 2).

4. Con ocasión del planteamiento de sendas cuestiones internas de inconstitucionalidad, el TC enjuicia en los autos de promoción de las mismas los óbices procesales que a los recursos de amparo de los que traen causa han opuesto quienes han comparecido y formulado alegaciones en el proceso constitucional en el trámite previsto al respecto en el art. 35.2 LOTC. El TC entiende que el examen de dichos óbices procesales es imprescindible dado que la cuestión interna de inconstitucionalidad, al igual que la cuestión de inconstitucionalidad, "no puede calificarse como un proceso de control abstracto sobre la constitucionalidad de una norma legal, sino que el fallo de la

2 Al auto formularon votos particulares los magistrados Martínez-Vares y Narváez Rodríguez, que en sus respectivos votos se remiten a los que formularon a las SSTC 127/2016, de 7 de julio, y 204/2016, de 1 de diciembre, mostrando su parecer opuesto a la aplicación que se hace en el auto de la cláusula de prevalencia. También formuló voto particular concurrente el magistrado Conde-Pumpido, al que se adhirieron los magistrados Ollero Tassara y Valdés Dal-Ré, basado no en la discrepancia con el contenido de la doctrina constitucional sobre la cláusula de prevalencia, ni en el sentido del fallo del auto, sino en la consideración de que se debió de «admitir a trámite la cuestión de inconstitucionalidad para, tras la correspondiente tramitación, resolver en sentencia la duda de constitucionalidad elevada, declarando la inconstitucionalidad sobrevenida del precepto autonómico cuestionado».

3 Véase infra p. 238. 
sentencia que recayere ha de tener siempre una proyección concreta sobre el resultado del proceso a quo». Carece de sentido elevar al Pleno una cuestión interna de inconstitucionalidad — se afirma — «si la sentencia que se dicte no va a poder ser aplicada a la resolución del correspondiente recurso de amparo, al tener que inadmitirse este último por estimación de un óbice de procedimiento" [ATC 3/2019 (Pleno), de 28 de enero, FJ 2; en el mismo sentido, ATC 23/2019 (Pleno), de 8 de abril, FJ 3].

5. Los motivos de especial trascendencia constitucional apreciados en los recursos de amparo resueltos durante este cuatrimestre han sido los siguientes: 1) [STC 155/2009, FJ 2 a)] que el recurso plantea un problema o afecta a la faceta de un derecho fundamental sobre el que no hay doctrina del TC (SSTC 1/2019 [Sala Segunda], de 14 de enero — sentencia penal absolutoria que no incurre en bis in idem procesal y no ha causado indefensión—; 3/2019 [Sala Segunda], de 14 de enero —resoluciones judiciales que desconocen la interdicción del doble enjuiciamiento penal en el ámbito transaccional-; 11/2019 [Sala Segunda], de 28 de enero, y 16/2019 [Sala Segunda], de 11 de febrero - detención policial lesiva del derecho a la asistencia letrada y a la libertad—; 12/2019 [Sala Segunda], de 28 de enero — paralización de los trabajos de una comisión parlamentaria de investigación-; 17/2019 [Sala Segunda], de 11 de febrero — inadmisión de una proposición de ley como consecuencia de la disconformidad manifestada por el gobierno para su tramitación por implicar un incremento de los créditos presupuestarios- ${ }^{4}$; 20/2019 [Pleno], de 12 de febrero, 38 y 39/2019 [Pleno] ${ }^{5}$, de 26 de marzo —inadmisión a limine de incidente de recusación—; 24/2019 [Sala Primera], de 25 de febrero - condena por la difusión en un diario digital de un hecho noticioso de relevancia pública—; 27/2019 [Pleno], de 26 de febrero —impugnación en amparo de auto de procesamiento-; 29 y 30/2019 [Pleno], de 28 de febrero, y 50/2019 [Pleno], de 9 de abril —impugnación de medida cautelar de prisión provisional comunicada y sin fianza-; 37/2019 [Pleno], de 26 de marzo, y 46/2019 [Pleno], de 8 de abril —sentencia dictada sin plantear cuestión prejudicial ante el TJUE cuando no concurrían los requisitos necesarios para apreciar la existencia de «acto aclarado»—; 49/2019 [Sala Segunda],

4 También se apreció como motivo de especial trascendencia constitucional que el asunto suscitado trasciende del caso concreto porque pudiera tener unas consecuencias jurídicas generales [STC 155/2009, FJ 2 g)].

5 También se apreció en estas sentencias como motivo de especial trascendencia constitucional que los recursos podían dar ocasión al TC para cambiar o aclarar su doctrina como consecuencia de un proceso de reflexión interna [STC 155/2009, FJ 2 b)]. 
de 8 de abril —resoluciones de letrado de la Administración de Justicia que impiden el control judicial de lo actuado en expediente de cuenta de abogado-; 52/2019 [Pleno], de 11 de abril -Acuerdo del presidente de la Cámara por el que se pospone la celebración de la sesión de investidura- ${ }^{6}$; ATC 4/2019 [Pleno], de 29 de enero - extradición para investigación y enjuiciamiento de delito cuya pena prevista en el país solicitante se extiende desde la pena de prisión a 10 ańos a la de cadena perpetua-); 2) [STC 155/2009, FJ 2 b)] que el recurso puede dar ocasión al TC para aclarar o cambiar su doctrina como consecuencia de un proceso de reflexión interna (SSTC 2/2019 [Sala Segunda], de 14 de enero - ampliación del permiso de paternidad para equipararlo en su duración al de maternidad - 7 ; 25/2019 [Sala Primera], de 25 de febrero - utilización de cámara oculta para obtener de forma subrepticia información en un ámbito privado-); 3) [STC 155/2009, FJ 2 b)] que el recurso puede dar ocasión al TC para aclarar o cambiar su doctrina como consecuencia de cambios normativos relevantes para la configuración del contenido del derecho fundamental (STC 47/2091 [Sala Segunda], de 8 de abril —inadecuada utilización de la dirección electrónica habilitada como cauce de comunicación del primer emplazamiento a la entidad demandada-); 4) [STC 155/2009, FJ 2 c)] que la posible vulneración del derecho fundamental que se denuncia pudiera provenir de la ley o de otra disposición de carácter general (SSTC 10/2019 [Sala Segunda], de 28 de enero, 15/2019 [Sala Segunda], de 11 de febrero, 23/2019 [Sala Segunda], de 25 de febrero, y 35 y 36/2019 [Sala Segunda], de 25 de marzo — resoluciones judiciales que acuerdan el archivo de causa penal al apreciar la falta de competencia jurisdiccional de los tribunales españoles-); 5) [STC 155/2009, FJ 2 g)] que el asunto trasciende del caso concreto porque plantea una cuestión jurídica de relevante y general repercusión social y económica (STC 31/2019 [Pleno], de 28 de febrero - ausencia de control judicial de las cláusulas abusivas que desconoce la primacía del derecho de la Unión Europa y la jurisprudencia del TJUE-); y 6) [STC 155/2009, FJ 2 g)] que el recurso de amparo pudiera tener consecuencias políticas generales (SSTC 41 y 42/2019 [Pleno], de 27 de marzo - supresión de trámites esenciales del procedimiento legislativo que afectan a los derechos de los parlamentarios-).

6 También se apreció como motivo de especial trascendencia constitucional que el asunto suscitado trasciende del caso concreto porque pudiera tener unas consecuencias jurídicas generales [STC 155/2009, FJ 2 g)].

7 También se apreció como motivo de especial trascendencia constitucional que el asunto suscitado trasciende del caso concreto porque pudiera tener unas consecuencias jurídicas generales [STC 155/2009, FJ 2 g)]. 
Siguiendo la tónica ya resaltada en anteriores crónicas, durante este cuatrimestre no son pocas tampoco las sentencias en las que el TC no se limita a enunciar el motivo o los motivos de especial trascendencia constitucional apreciados, sino que además explica por qué concurren, precisando cuál es el problema o la faceta del derecho fundamental nuevos que plantea el recurso o los aspectos novedosos que presenta respecto a precedentes pronunciamientos o sobre los que va a versar la aclaración o el cambio de doctrina (SSTC 3/2019 [Sala Segunda], de 14 de enero, FJ 2; 24/2019 [Sala Primera], de 25 de febrero, FJ 2; 25/2019 [Sala Primera], de 25 de febrero, FJ 2 c); 31/2019 [Pleno], de 28 de febrero, FJ 2; 37/2019 [Pleno], de 26 de marzo, FJ 3 b) y c); 46/2019 [Pleno], de 8 de abril, FJ 3 c), entre otras).

En relación con el requisito de justificar la especial trascendencia constitucional, la STC 1/2019 (Sala Segunda), de 14 de enero ${ }^{8}$, estima que es suficiente para considerarlo satisfecho con que los razonamientos de la demanda permitan «conectar materialmente la alegada lesión [del derecho fundamental] con uno de los supuestos [de la STC 155/2009, FJ 2] en los que cabe apreciar que el contenido del recurso justifica una decisión sobre el fondo en razón de su especial trascendencia constitucional». En otras palabras, basta que los razonamientos contenidos en la demanda pongan de relieve «los datos necesarios para justificar la proyección objetiva del amparo solicitado» [FJ $2 \mathrm{c}$ )].

De otra parte, la apreciación del requisito de la especial trascendencia constitucional no limita la extensión del objeto del recurso de amparo, reduciéndolo a las cuestiones que el TC estima que tienen especial trascendencia constitucional, ni tampoco limita, por tanto, la razón de decidir sobre el fondo del recurso. De manera que la función objetiva del recurso de amparo, tras la reforma llevada a cabo por la Ley Orgánica 6/2007, de 24 de mayo, «no elimina la función de tutela judicial subjetiva de la posición jurídica del actor, sino que debe conciliarse con sus exigencias». Así pues, las cuestiones que en la fase de admisión del recurso determinaron la apreciación de su especial trascendencia constitucional no tienen que traducirse «forzosa y miméticamente en el núcleo de la decisión que finalmente se adopte, toda vez que la estructura del razonamiento, el orden conforme al cual han de estudiarse las quejas ante nosotros esgrimidas, u otras razones pueden impedirlo». En definitiva, el objeto del recurso de amparo no queda limitado a la cuestión o cuestiones que el TC ha estimado que revisten especial trascendencia constitucional en la fase de admisión. En aplicación de esta doctrina, se rechaza en la STC 25/2019 [Sala Primera], de 25 de febrero', la alegación de

8 Véanse infra pp. 231 y 259-260.

$9 \quad$ Véase infra pp. 232 y 255-257. 
las partes personadas en el recurso de que el TC no debería resolver sobre las cuestiones abordadas en la sentencia impugnada que no hubieran satisfecho el requisito de la especial trascendencia constitucional (FJ 3).

6. El TC en los AATC 4 y 10/2019 (Pleno), de 29 de enero y de 14 de febrero, respectivamente, inadmite a trámite, por carecer de fundamento las vulneraciones aducidas, sendas demandas de amparo promovidas contras las resoluciones judiciales que han accedido en vía jurisdiccional a la extradición de los recurrentes a la República Popular China para su enjuiciamiento por un delito de estafa cuyo perjuicio total es de notoria importancia y afecta a una generalidad de personas.

En tanto que en el ATC $10 / 2019^{10}$ se omite cualquier consideración sobre la especial trascendencia constitucional del recurso, sin embargo en el ATC 4/2019 ${ }^{11}$ se aprecia la especial trascendencia constitucional en relación con la alegada vulneración del derecho a la proporcionalidad de la reacción

10 A este auto formuló voto particular el magistrado Xíol Ríos, al que se adhiere el magistrado Valdés Dal- Ré, en el que manifiesta su discrepancia «con los antecedentes fácticos, la fundamentación jurídica y el fallo, que considera que hubiera debido ser de admisión». Tras resaltar que la mayoría ha omitido cualquier consideración sobre el motivo de especial trascendencia constitucional del recurso, argumentando directamente sobre la inexistencia de las lesiones de derechos fundamentales denunciadas, se identifican en el voto dos motivos de especial trascendencia constitucional: que el recurso plantea un problema o afecta a la faceta de un derecho fundamental sobre la que no hay doctrina del TC [STC 155/2009, FJ 2 a)] y que podría servir de elemento para «iniciar un proceso de reflexión interna respecto a la conveniencia de hacer converger la jurisprudencia constitucional con la del Tribunal Europeo de Derechos Humanos y del Tribunal de Justicia de la Unión Europea sobre determinados aspectos relativos (i) al estándar de prueba en relación con los riesgos alegados para aplicar el principio de no devolución a las extradiciones y (ii) a las obligaciones específicas que deben analizarse cuando está implicada la posibilidad de imponer una pena de prisión perpetua al reclamado».

11 A este auto formularon sendos votos particulares la vicepresidenta Roca Trías y el magistrado Xiol Ríos. Para la vicepresidenta «la apreciada ausencia de doctrina constitucional, como motivo que dota de especial trascendencia constitucional al recurso, conducía a entender que procedía la admisión del recurso de amparo y no el dictado de un auto, por una cuestión de motivación». A su juicio, la admisión a trámite del recurso «no se mostraba solo posible, sino [...] obligada», pues «la falta de lesión no era "patente, clara y notoria" (ATC 52/1980, FJ 2), ni podía serla, dada la ausencia de doctrina constitucional previa para poder dar respuesta a la cuestión planteada, por lo que no procedía la inadmisión del recurso de amparo, sino su tramitación y resolución por sentencia”. 
penal (arts. 17.1 y $25 \mathrm{CE}$ ), dada la previsión legal abstracta que en el ordenamiento jurídico chino se contempla para el delito provisionalmente imputado para el que se solicita la extradición, cuya pena abarca un rango que va de los diez años de prisión a la cadena perpetua. Para el TC la cuestión planteada por la recurrente consiste en que en el recurso de amparo se formule y proyecte externamente un juicio abstracto de proporcionalidad de la referida previsión penal que nunca ha sido abordado en un proceso de amparo, «lo que justifica que este pronunciamiento revista la forma de auto, pues permite a este Tribunal explicar y hacer públicas las razones que conducen a la decisión de inadmisión» (FJ 2).

7. En las SSTC 11/ y 16/2019 (Sala Segunda), de 28 de enero y de 11 de febrero, respectivamente, se encuadran como recursos de amparo del art. 43 LOTC, esto es, contra actos de la administración pública, en vez del art. 44 LOTC, es decir, contra resoluciones judiciales, los promovidos contra la actuación de los funcionarios policiales que procedieron a la detención de los demandantes de amparo, pues la vulneración de los derechos fundamentales que se denuncian — derecho a la asistencia letrada (art. 24.2 CE) y a la libertad (art. $17 \mathrm{CE}$ ) - son imputables exclusivamente a la actuación policial, no al órgano judicial que desestimó la solicitud de habeas corpus, que ni siquiera había ordenado aquella actuación. Como consecuencia del apuntado encuadramiento de los recursos de amparo, en las sentencias se declara su inadmisión a trámite por extemporaneidad, al haber sido presentadas las demandas una vez transcurrido el plazo de veinte días que para su interposición establece el art. 43 LOTC.

Para el magistrado Xiol Ríos, además del motivo de especial trascendencia constitucional apreciado en la fundamentación jurídica del auto, concurría adicionalmente como motivo de especial trascendencia constitucional que «el recurso podía servir de elemento para, en los términos expuestos en la STC 155/2009, de 25 de junio, FJ 2, iniciar un proceso de reflexión interna respecto a la conveniencia de hacer converger la jurisprudencia constitucional con la del Tribunal Europeo de Derechos Humanos y del Tribunal de Justicia de la Unión Europea sobre determinados aspectos relativos (i) al estándar de prueba en relación con los riesgos alegados para aplicar el principio de no devolución a las extradiciones y (ii) a las obligaciones específicas que deben analizarse cuando está implicada la posibilidad de imponer una pena de prisión perpetua al reclamado». Además el autor del voto considera que «no solo no puede descartarse en este análisis preliminar de admisibilidad el contenido constitucional de determinadas invocaciones de derechos fundamentales, sino que, además, las causas de especial trascendencia constitucional concurrentes hubiera debido resultar prevalentes y prioritarias para demandar un pronunciamiento sobre el fondo con la siempre ilustre opinión del Ministerio Fiscal». 
8. En relación con el requisito del agotamiento de la vía judicial previa del art. 44.1. a) LOTC, el TC desestima en la STC 15/2019 (Sala Segunda), de 11 de febrero, el óbice procesal opuesto a la demanda de amparo por el incumplimiento de dicho requisito, al no haber interpuesto los demandantes de amparo recurso de casación contra la resolución judicial que había acordado el sobreseimiento de la causa penal por falta de jurisdicción de los tribunales españoles (disposición transitoria única de la Ley Orgánica 1/2014). Se razona en la sentencia que la regulación legal y la doctrina jurisprudencial existentes no eran inequívocas en torno a la procedencia de dicho recurso, de modo que, conforme a una reiterada doctrina del TC, no podía imponerse a los demandantes «la carga de superar complejos problemas de interpretación, alterando las evidencias doctrinales y normativas, pese a la instrucción de recursos" contenida en la resolución impugnada. Se recuerda que "diligencia procesal que debe tener quien acude ante los órganos judiciales en defensa de sus derechos no debe llegar al extremo de exigirle a priori la interposición de recursos de dudosa viabilidad» (FJ 3).

Por su parte, en la STC 31/2019 [Pleno], de 28 de febrero $^{12}$, el TC entiende que en los supuestos en los que el recurso de amparo se dirija contra la resolución judicial que resuelve el incidente de nulidad de actuaciones y se le atribuya la lesión autónoma de un derecho fundamental con ocasión de la nulidad solicitada, al demandante de amparo no le es exigible que plantee un nuevo incidente de nulidad de actuaciones contra aquella resolución antes de interponer el recurso de amparo. Si bien se precisa en la sentencia que en caso de promover dicho incidente tampoco cabe apreciar que el recurso de amparo resulte extemporáneo como consecuencia de la interposición de un recurso manifiestamente improcedente (FJ 3).

9. El TC durante este cuatrimestre ha continuado resolviendo algunos recursos de amparo interpuestos en relación con la causa seguida ante la Sala de lo Penal del Tribunal Supremo por delitos de rebelión, sedición, malversación de caudales públicos y desobediencia como consecuencia del denominado proceso soberanista en Cataluña.

En lo que a este apartado de la crónica se refiere, las SSTC 20/2019 (Pleno), de 12 de febrero, y 38 y 39/2019 (Pleno), de 26 de marzo, inadmiten por prematuros tres recursos de amparo promovidos contra las resoluciones judiciales que a su vez inadmitieron a limine de los incidentes de recusación presentados contra el magistrado instructor y contra los magistrados de la Sala de lo Penal del Tribunal Supremo.

12 Véanse infra pp. 12 y 41-42. 
La cuestión nuclear examinada gira en torno a la posibilidad de impugnar en amparo resoluciones interlocutorias dictadas en un proceso penal en curso.

En aplicación de la doctrina sentada en las SSTC 129 a 131/2018 (Pleno), de 12 de diciembre ${ }^{13}$, se inadmiten en las SSTC 20 y 38/2019 las demandas de amparo por prematuras, pues las resoluciones judiciales que ponen término a un incidente de recusación no suponen el agotamiento de la vía judicial previa, ya que en la fase preliminar del juicio oral, tanto en el procedimiento abreviado, como en el proceso ordinario por delito, es posible hacer valer y obtener a través de las cuestiones de previo pronunciamiento la reparación de supuestas vulneraciones de derechos fundamentales que se aleguen por las partes. Esta falta de agotamiento de la vía judicial previa al recurso de amparo se aprecia no solo en relación en el pronunciamiento de fondo sobre la recusación formulada, sin que se extiende también a las supuestas vulneraciones de derechos procesales que se hubieran podido producir durante la tramitación del incidente de recusación (FFJJ 2 y 3 , respectivamente).

Sustancialmente distinta es, sin embargo, la fundamentación en la que se basa en la STC 39/2019 la inadmisión por prematura de la demanda de amparo contra las resoluciones judiciales que inadmitieron la recusación formulada contra los magistrados de la Sala de lo Penal del Tribunal Supremo. Según se afirma en la sentencia, dado que el incidente fue resuelto por la Sala Especial del art. $61 \mathrm{LOPJ}$, «no existe en apariencia ningún remedio procesal para recabar un pronunciamiento sobre la cuestión» de modo que «la lesión alegada, de concurrir, no podrá ya ser reparada en el transcurso del proceso penal pendiente». Circunstancia que, no obstante, no impide apreciar el carácter prematuro del recurso de amparo, pues «la acción de amparo constitucional [...] está vinculada, entre otros requisitos, a la concurrencia de un gravamen ligado a la efectividad de la lesión alegada dimanante de una sentencia condenatoria», gravamen que en este caso no se habría producido en el momento en que se interpuso la demanda de amparo por no haber finalizado aún el proceso penal (FJ 3).

Por su parte, las SSTC 29 y 30/2019 (Pleno), de 28 de febrero ${ }^{14}$, inadmitieron por prematuras, en aplicación de la doctrina constitucional de las citadas SSTC 129 a 131/2018, de 12 de diciembre, las quejas planteadas en sendos recursos de amparo en los que se cuestionaba, con invocación del derecho al juez ordinario predeterminado por la ley (art. 24.2 CE), la falta

\footnotetext{
13 Reseñadas en la Revista Española de Derecho Constitucional, núm. 115, 2019, pp. 261-263.

14 Véase infra pp. 265-266.
} 
de competencia de la Audiencia Nacional para conocer del delito de sedición que se imputaba a los recurrentes. Como se razona en ambas sentencias, los recursos de amparo devienen prematuros, ya que los demandantes todavía tienen la oportunidad de plantear la declinatoria de jurisdicción e incluso, en su caso, formular ante el Tribunal de enjuiciamiento su queja como artículo de previo pronunciamiento (arts. 26 in fine y 666.1 LECrim) [FFJJ 2 b) y 2 a), respectivamente].

Y, en fin, por su parte, la STC 27/2019 (Pleno), de 26 de febrero, inadmitió también por prematura la demanda de amparo promovida contra el auto de procesamiento de los recurrentes, pues las vulneraciones constitucionales alegadas - juez imparcial y juez ordinario predeterminado por la ley (art. 24.2 CE), derecho a la tutela judicial efectiva (art. 24.1 CE) y principio de legalidad en materia penal (art. 25.1 CE) — pueden hacerse valer durante el desarrollo del proceso penal que aún no ha concluido (FFJJ 6 y 7 )

10. En la STC 52/2019 (Pleno), de 11 de abril, se declara la extinción por pérdida sobrevenida de su objeto del recurso de amparo promovido por los diputados de un grupo parlamentario contra el acuerdo del presidente del Parlamento de Cataluña de posponer la celebración del pleno de investidura del candidato a la presidencia de la Generalitat don Carles Puigdemont i Casamajó. El TC entiende que las posteriores propuestas de candidatos efectuadas por el presidente de la Cámara han modificado de manera sustancial la controversia toda vez que han desbloqueado "la situación de parálisis institucional que denuncian los recurrentes». Con dichas propuestas, aunque alguna de ellas no haya llegado ni siquiera a tramitarse, "se inició el procedimiento de elección de presidente de la Generalitat [...] y el acto parlamentario objeto del presente recurso de amparo agotó su eficacia jurídica». En consecuencia, el TC entiende que resulta innecesario un pronunciamiento respecto al mismo.

11. En cuanto al alcance de los pronunciamiento de las sentencias recaídas en los procesos de amparo, en la STC 1/2019 (Sala Segunda), de 14 de enero $^{15}$, aunque se desestima la demanda, se declara abierta la vía correspondiente para que el recurrente pueda instar la declaración de responsabilidad patrimonial de la Administración pública al objeto de ser resarcido por las graves lesiones padecidas como consecuencia de un accidente paracaidista, señalándose la fecha de notificación de la sentencia de amparo como dies a quo del cómputo del plazo para el ejercicio de las acciones pertinentes (FJ 3).

15 Véase supra p. 5 e infra pp. 38-39. 
Por su parte, el TC en la STC 25/2019 (Sala Primera), de 25 de febrero ${ }^{16}$, que estima parcialmente el recurso de amparo por vulneración de los derechos a la intimidad personal, a la propia imagen y al honor por la emisión de una información obtenida con cámara oculta, declara la nulidad de la sentencia de la Sala de lo Civil del Tribunal Supremo, pero no retrotrae las actuaciones para que se pronuncie sobre el quantum de la indemnización solicitada por el recurrente, al tratarse de una cuestión que ya se había debatido entre las partes en la primera y en la segunda instancia, sin que en el recurso de casación se planteasen argumentos que pudieran ser tenidos en cuenta para alterar el quantum indemnizatorio fijado en la apelación. En consecuencia, el TC declara firmes los pronunciamientos de la sentencia de apelación que estimaron las vulneraciones de los derechos fundamentales denunciadas y fijaron el quantum indemnizatorio por dichas vulneraciones (FJ 11).

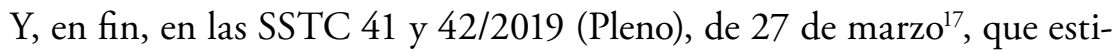
man los recursos de amparo promovidos por los diputados de un grupo parlamentario contra los acuerdos de la Mesa y del Pleno del Parlamento de Cataluña que suprimieron fases esenciales del procedimiento legislativo en la tramitación de sendas proposiciones de ley, el otorgamiento del amparo tiene efectos meramente declarativos, pues se circunscribe a apreciar la vulneración de los derechos fundamentales de los demandantes de amparo, pero sin acordar la nulidad de los acuerdos impugnados, pues el TC ya había declarado en sendos recursos de inconstitucionalidad la inconstitucionalidad y nulidad de las leyes aprobadas como consecuencia de la tramitación de las referidas proposiciones de ley (FFJJ 7) ${ }^{18}$.

\section{FUENTES DEL DERECHO}

1. La doctrina sentada en la STC 128/2018 (Pleno), de 29 de noviembre $^{19}$, conforme a la cual la reforma (2015) del art. 86.3 de la Ley reguladora de la Jurisdicción Contencioso-Administrativa, en lo que atañe a la competencia para conocer del nuevo recurso de casación basado en la infracción de normas emanadas de la comunidad autónoma, no vulnera la reserva de ley orgánica del art. 122.1 CE, ha sido reiterada en el cuatrimestre que ahora se

\footnotetext{
16 Véase supra pp. 226-227 e infra pp. 255-257.

17 Véase infra p. 259.

18 Juan Carlos Duque Villanueva.

19 Reseñada en Revista Española de Derecho Constitucional, núm. 115, 2019, pp. 265-266.
} 
reseña por dos sentencias de Sala, que desestiman otras tantas cuestiones de inconstitucionalidad idénticas planteadas por el mismo órgano judicial. Se trata de la STC 18/2019 (Sala Segunda), de 11 de febrero ${ }^{20}$, y de la STC 26/2019 (Sala Primera), de 25 de febrero. Ambas repiten la doctrina referida, según la cual las secciones a las que se refiere el precepto cuestionado son una variedad de las secciones "funcionales», ya previstas en la LOPJ, por lo que no constituyen órganos judiciales distintos a los efectos de la reserva del art. 122.1 $\mathrm{CE}$, no siendo necesario, por tanto, que sean reguladas por disposiciones de rango orgánico.

2. La STC 31/2019 (Pleno), de 28 de febrero ${ }^{21}$, que resuelve un recurso de amparo interpuesto contra resoluciones judiciales recaídas en un procedimiento de ejecución hipotecaria, da ocasión de nuevo al TC para pronunciarse sobre el efecto vinculante de las directivas europeas conforme han sido interpretadas por el Tribunal de Justicia de la Unión Europea (TJUE). La STC 31/2019 concluye que esas resoluciones lesionan el derecho a la tutela judicial efectiva sin indefensión (art. 24.1 CE) de la recurrente porque rechazan un incidente de nulidad de actuaciones en el que denunciaba la abusividad de la cláusula de vencimiento anticipado incluida en un contrato de préstamo hipotecario sin tomar en consideración la doctrina sentada por el TJUE en su sentencia de 26 de enero de 2017 (asunto Banco Primus, S.A.) sobre la interpretación de la Directiva 93/13/CEE, relativa a las cláusulas abusivas en los contratos celebrados con consumidores y sin entrar a analizar la posible nulidad de la cláusula objeto del incidente de nulidad, ni plantear, en su caso, cuestión prejudicial ante el TJUE ${ }^{22}$. El TC declara, con cita de doctrina precedente, que le corresponde velar por el respeto del principio de primacía del derecho de la Unión Europea cuando exista una interpretación auténtica efectuada por el TJUE; y, en particular, que el indicado principio

20 La STC 18/2019 cuenta con dos votos particulares, los mismos que la STC 128/2018, a los que se remiten los magistrados disidentes Xiol Ríos y Enríquez Sancho, quienes consideran que las secciones a las que se refiere el precepto cuestionado no son meras divisiones funcionales de las Salas de lo Contencioso-Administrativo, sino órganos judiciales nuevos, cuya constitución está reservada a la Ley Orgánica del Poder Judicial por el art. 122.1 CE.

21 Véanse supra p. 8 e infra pp.41-42.

22 La STC 31/2019 contiene un extenso voto particular discrepante del magistrado Enríquez Sancho, en el que sostiene que el TC debió denegar el amparo, pues entiende que la aplicación de los criterios sobre el control de oficio de la cláusula abusiva que resultan de la jurisprudencia del Tribunal de Justicia de la Unión Europea, rectamente entendida, llevaban necesariamente a desestimar el recurso de amparo. 
obligaba al órgano judicial en el asunto enjuiciado a aplicar el art. 6.1 de la Directiva 93/13/CEE tal como había sido interpretado por el TJUE o, en su caso, a plantear la cuestión prejudicial, si se le ofrecían dudas sobre el alcance de la norma europea en relación con el supuesto concreto sometido a enjuiciamiento.

Se trata pues de un pronunciamiento que reitera otros anteriores sobre la posición del TC como garante del principio de primacía del derecho de la Unión Europea y que abunda en la relativización (al menos en lo que a los recursos de amparo se refiere) del axioma de la doctrina constitucional según el cual ese derecho no integra el canon de control de constitucionalidad.

En similar sentido, pero yendo más lejos, la STC 37/2019 (Pleno), de 26 de marzo ${ }^{23}$, estima el recurso de amparo planteado por la Administración General del Estado en el asunto del «bono social eléctrico», porque la sentencia del Tribunal Supremo impugnada resolvió el litigio declarando inaplicable el precepto legal en el que se fundaba el reglamento recurrido, al entenderlo incompatible con la Directiva 2009/72/CE, sin plantear la cuestión prejudicial ante el TJUE24.

Si bien el Tribunal Supremo había explicitado en su sentencia las razones que le llevaban a inaplicar directamente la ley española, sin necesidad por tanto de plantear previamente la cuestión prejudicial (en suma, que la contradicción de la norma legal interna con la Directiva 2009/72/CE era patente conforme a los criterios de la doctrina del «acto aclarado» del TJUE), la STC $37 / 2019$ rechaza que en el supuesto enjuiciado concurriesen los requisitos necesarios para apreciar la existencia de un «acto aclarado» respecto del problema interpretativo suscitado, por lo que concluye que el Tribunal Supremo venía obligado a elevar cuestión prejudicial ante el TJUE, conforme al art. 267 del Tratado de Funcionamiento de la Unión Europea; al no hacerlo así, el Tribunal Supremo habría vulnerado el derecho a un proceso con todas las garantías de la Administración General del Estado. La preterición de la aplicación de la norma legal, realizada al margen del sistema de fuentes, produciría la vulneración del derecho al debido proceso que garantiza el art. 24.2 CE.

Véase infra p. 263-264.

24 La STC 37/2019 es cabecera de una serie de asuntos idénticos; en el periodo considerado en esta crónica, se ha dictado la STC 46/2019 (Sala Segunda), de 8 de abril, que se remite a lo razonado en la STC 37/2019. Siguen, ya fuera del periodo considerado las SSTC 53, 54 y 57/2019 (Sala Segunda), todas de 6 de mayo; las SSTC 58 y 59/2019 (Sala Primera), ambas de 6 de mayo también; las SSTC 65, 66, 69 y 70/2019 (Sala Segunda), todas de 20 de mayo; y las SSTC 67, 68 y 71/2019 (Sala Primera), todas de 20 de mayo también. 
Para alcanzar esta conclusión la STC 37/2019 se ve obligada a aplicar un «doble canon de enjuiciamiento» conforme al cual la decisión del órgano judicial de inaplicar la norma interna sin plantear cuestión prejudicial puede ser discutida desde la perspectiva del derecho a la tutela judicial efectiva (art. 24.1 $\mathrm{CE}$ ), en cuyo caso el TC habría de emplear un canon flexible, que se limita a examinar si el órgano judicial ha ofrecido una motivación razonable de su decisión. Ahora bien, esa decisión también puede ser enjuiciada aplicando el canon más incisivo propio del derecho a un proceso con todas las garantías (art. 24.2 CE), que se entenderá vulnerado si el órgano judicial inaplica la norma legal interna por entenderla incompatible con el derecho de la Unión Europea, sin plantear la cuestión prejudicial, cuando no concurran los criterios de la doctrina del TJUE sobre el «acto claro» o el «acto aclarado» (FJ 4).

Los problemas que suscita la aplicación de este canon más incisivo los pone de relieve el voto particular discrepante a la STC 37/2019 del magistrado Ollero Tassara. La contradicción de la ley con la Constitución plantea un problema de validez que solo puede resolver el TC, por lo que el juez ordinario que inaplica la ley sin elevar cuestión de inconstitucionalidad vulnera el derecho a un proceso con todas las garantías (art. 24.2 CE). En cambio, la contradicción de la ley con el derecho de la Unión Europea plantea un problema de estricta aplicabilidad que debe resolver el juez ordinario; por tanto, la decisión sobre si en un caso resulta aplicable la norma europea o la nacional y si resulta procedente la formulación de la cuestión prejudicial es de legalidad ordinaria y por tanto reservada a los jueces y tribunales (art. 117.3 CE). Al aplicar ese canon estricto, el TC se considera obligado a verificar la concurrencia de los requisitos de la doctrina del TJUE sobre el «acto claro» o el «acto aclarado", de forma que se ve abocado a descender a cuestiones de mera legalidad, con la consiguiente invasión de la reserva de jurisdicción. En suma, quien ha de verificar si concurren o no tales requisitos en el supuesto concreto, a fin de decidir si procede o no promover la cuestión prejudicial ante el TJUE, es el juez ordinario; al TC le corresponde únicamente verificar que la decisión judicial sometida a su escrutinio es motivada y razonable ${ }^{25}$.

25 Por otra parte, como también pone de relieve el voto particular, la función de la doctrina del TJUE sobre el «acto claro» o el "acto aclarado» es asegurar la uniformidad en la interpretación del derecho de la Unión Europea, tanto cuando el órgano judicial aplica la ley nacional, descartando la contradicción con la normativa europea, como cuando la inaplica por considerarla desplazada por el derecho europeo. En cambio, la STC 37/2019 acaba utilizando esa doctrina a otros efectos, esto es, para favorecer la aplicación de la ley nacional en detrimento del derecho de la Unión Europea. 
3. La STC 9/2019 (Pleno), de 17 de enero, desestima una cuestión prejudicial de validez planteada en relación con una norma foral tributaria (Norma Foral 4/2014, de 26 de febrero, de las Juntas Generales de Álava, reguladora del impuesto sobre el valor de la producción de la energía), al descartar la supuesta infracción de los principios de seguridad jurídica e interdicción de la retroactividad (art. 9.3 CE), en materia tributaria, que invocaba el órgano judicial promotor de la cuestión. La disposición concretamente cuestionada establece que la Norma Foral 4/2014, publicada oficialmente el 19 de enero de 2014, y que se enmarca en el concierto económico con la Comunidad Autónoma del País Vasco, «tendrá efectos desde el 1 de enero de 2013».

Conforme a la STC 9/2019, la disposición cuestionada no constituye - frente a lo que sostiene el órgano judicial que plantea la cuestión- un supuesto de retroactividad auténtica, sino que es mera consecuencia de la aplicación de la normativa reguladora del concierto económico (Ley 12/2002, de 23 de mayo, y art. 41 del Estatuto de Autonomía del País Vasco), de la que deriva la necesidad de proceder a la adaptación del concierto por mutuo acuerdo (de la Administración del Estado con las diputaciones forales y el Gobierno Vasco) cuando se establezcan nuevas figuras tributarias estatales, como sucedió precisamente con la Ley 15/2012, de 27 de diciembre, que creó el impuesto sobre el valor de la producción de la energía eléctrica, con efectos de 1 de enero de 2013, y que dio lugar a la modificación del concierto por la Ley $7 / 2014$, de 21 de abril, en cuya virtud se declara concertado el nuevo impuesto desde la indicada fecha; esta concertación fue ratificada por la Norma Foral 4/2014 (FJ 5).

No estamos, en suma, según el TC, ante un problema de retroactividad del impuesto sobre el valor de la producción de la energía eléctrica en el territorio de Álava, pues «el tributo existe desde que fue creado por la Ley estatal 15/2012», sino que se trata sencillamente de "la retroactividad de los efectos de su concertación a efectos de que se integre en el respectivo sistema tributario de cada territorio histórico [...] para hacer posible su exacción, gestión, liquidación, recaudación e inspección por la Diputación Foral» correspondiente. De suerte que — concluye la STC 9/2019 - el periodo de tiempo que media entre la creación del tributo estatal y su efectiva incorporación, tras el correspondiente acuerdo, a los sistemas tributarios de los territorios históricos, no afecta a la existencia del tributo como tal y, por tanto, hace que no nos hallemos ante un supuesto de retroactividad auténtica en el que el órgano judicial ha fundado la duda sobre la infracción del art. 9.3 CE», lo que conduce a la desestimación de la cuestión prejudicial de validez (FJ 5 ${ }^{26}$.

26 Herminio Losada González. 


\section{ORGANIZACIÓN TERRITORIAL DEL ESTADO}

1. En el periodo analizado en la presente crónica el TC se ha planteado la aceptación de aquellos desistimientos de los recursos de inconstitucionalidad de carácter competencial que se habrían producido como consecuencia del cambio de Gobierno que tuvo su origen en la moción de censura de junio de 2018. Los desistimientos derivados de un cambio del signo político del Gobierno suelen ser una práctica habitual; sin embargo, en este caso, aquellos han tenido una peculiaridad, pues han sido fundamentalmente desistimientos parciales.

La razón para esta novedosa forma de proceder por parte del Gobierno de la Nación habría sido la existencia de doctrina previa del TC sobre la cuestión objeto del procedimiento en el que se desiste, así como los propios términos de esa doctrina previa.

En efecto, los desistimientos parciales se han producido sobre todo en relación con determinadas impugnaciones de leyes de vivienda autonómicas, cuestión sobre la que ya había, en el momento en el que se plantearon aquellos, abundante doctrina previa recogida en las SSTC 93/2015, de 14 de mayo; $16 / 2018$, de 22 de febrero; 80/2018, de 5 de julio; 97/2018, de 19 de septiembre, y STC 106/2018, de 4 de octubre.

Este hecho es el que parece justificar que el Estado desista solo de aquellas impugnaciones sobre las que sería posible anticipar, con base en esa doctrina previa, un pronunciamiento del TC en el sentido de rechazar la nulidad de los preceptos autonómicos impugnados. Por el contrario, el Gobierno decide mantener los recursos en relación con las impugnaciones de aquellos otros preceptos en los que los pronunciamientos del TC en relación con preceptos similares de otras normas autonómicas hubiesen sido de inconstitucionalidad y nulidad.

Así, la justificación del mantenimiento parcial del recurso por parte del Gobierno se funda en el hecho de que en relación con cuestiones similares a las que son materia de controversia el TC ya se habría pronunciado declarando la nulidad de los preceptos autonómicos equivalentes, lo que aconsejaría la prosecución del recurso de inconstitucionalidad respecto de tales preceptos.

En relación con el desistimiento, la Ley Orgánica 2/1979, de 3 de octubre, del TC no contiene una regulación completa y acabada de su régimen jurídico en los procesos constitucionales. Es el art. 80 LOTC, en la redacción que le ha dado la Ley Orgánica 15/2015, de 16 de octubre, el que prevé que se aplicarán, con carácter supletorio, los preceptos de la Ley Orgánica del Poder Judicial y de la Ley de Enjuiciamiento Civil, entre otras materias, en cuanto al «desistimiento». 
Sin perjuicio de tal remisión, el TC ha establecido, incluso después de la reforma del art. 80 LOTC en 2015 que es la que realiza aquella, que «a pesar de ser rogada la jurisdicción constitucional, no opera aquí con toda su plenitud el principio dispositivo, por lo que el Tribunal no queda vinculado de forma absoluta por la voluntad unilateral de quien formula el desistimiento", si bien ha indicado que "tampoco es dudoso que este como titular del interés cuya actuación sirve de soporte a su legitimación activa en el proceso, ha de ser atendido salvo que otras consideraciones prevalentes lo impidan». Así, en las diversas resoluciones, autos o sentencias, donde se ha admitido el abandono del proceso, se alude a dos circunstancias para ponderar la viabilidad de un desistimiento: por una parte, «que las demás partes personadas no se opongan a esta pretensión» y, por otra parte, «la existencia de un interés general público que pudiera resultar lesionado por la admisión del desistimiento».

Estas dos circunstancias se encuentran ponderadas en el caso de las recientes SSTC 5/2019, de 17 de enero ${ }^{27}$, y 21/2019, de 14 de febrero, donde se procede a admitir los desistimientos parciales solicitados por el abogado del Estado, al no existir oposición de las restantes partes personadas, y no advertirse un interés constitucional que aconseje un pronunciamiento del TC.

En las igualmente recientes SSTC 8/2019, de 17 de enero ${ }^{28}$, 13/2019, de 31 de enero, no se realiza referencia alguna al interés constitucional y se procede a la admisión de los desistimientos parciales simplemente por no haberse opuesto los representantes autonómicos.

Las dos circunstancias vuelven a exigirse en el reciente ATC 20/2019, de 26 de marzo, si bien de manera peculiar pues se considera que en relación al desistimiento de un recurso frente a una norma del Estado planteado por el recurrente, el Gobierno de Navarra, y al que no se opone el representante del Estado, no sería necesario considerar si concurre un interés constitucional que justifique la prosecución del proceso, habida cuenta de que la misma ley ha sido objeto también del recurso de inconstitucionalidad planteado por más de cincuenta diputados en el que, se impugnan, entre otros, los mismos preceptos que en el interpuesto por el Gobierno de Navarra.

Con respecto al desistimiento del único precepto no impugnado en el recurso de los cincuenta diputados y que sí se impugnó en su día por el Gobierno de Navarra, el TC excluye que exista un interés constitucional que justifique la prosecución del proceso, por cuanto el actor no mantiene ya su propia competencia.

27 Véase supra p. 222.

28 Véase supra p. 223. 
2. La STC 51/2019, de 11 de abril, resuelve el recurso de inconstitucionalidad interpuesto por más de cincuenta diputados del Grupo Parlamentario Popular contra distintos preceptos de la Ley del Parlamento de Cataluña 12/2009, de 10 de julio, de Educación.

La resolución del asunto le ha llevado al TC casi diez años, lo que supone retrotraerse a plazos de resolución de otros tiempos, pues en los últimos años aquellos se habían visto acortados considerablemente, como pudimos constatar en la anterior crónica. Parece tratarse, no obstante, de un supuesto singular, pues por lo general los asuntos que resuelve el TC son en el momento presente relativamente cercanos en el tiempo.

Más allá de las cuestiones concretas que se plantean, la STC 51/2019 es doctrinalmente relevante por la recapitulación que realiza de la cuestión de la reproducción parcial de las normas del Estado en las normas autonómicas. Se trata de una técnica normativa que, a pesar de ser propicia en el marco de un Estado compuesto, con múltiples centros de emanación de disposiciones normativas, encierra, señala el TC, algunos peligros con relevancia constitucional. Así, recuerda el TC que esta técnica duplicativa se presta a un margen de inseguridad y error, y siempre queda sometida a la necesidad de atender en su día a las eventuales modificaciones de las normas estatales así «incorporadas» al ordenamiento autonómico.

Los problemas competenciales de repetición de contenidos normativos en las normas autonómicas han aparecido tanto en relación con las competencias exclusivas del Estado como en relación con las competencias estatales de carácter básico.

En relación con las competencias exclusivas del Estado, la doctrina del TC ha sostenido con contundencia que «la reproducción de normas estatales por leyes autonómicas, además de constituir una deficiente técnica legislativa, incurre en inconstitucionalidad cuando esa reproducción normativa se concreta en normas relativas a materias en las que la Comunidad Autónoma carece de competencia».

La reiteración del contenido de una norma estatal constituye para el TC una invasión de competencias cuando se produce en materias cuya regulación no corresponde a una comunidad autónoma, porque la reiteración de las disposiciones estatales por el regulador autonómico produce, con independencia de que su contenido sea acorde con la regulación estatal, una invasión competencial sobre la materia correspondiente y genera una confusión que es lesiva de la seguridad jurídica. Efecto que además, de ordinario, puede evitarse sencillamente mediante la técnica de la remisión normativa expresa.

El TC únicamente ha admitido una excepción en el ámbito concreto de la legislación procesal y que se justifica en particularidades de derecho 
sustantivo autonómico, a las que hace referencia expresa el propio art. 149.1.6 CE. En efecto, el TC habría admitido «aquellos supuestos en que la reiteración simplemente consista en incorporar a la normativa autonómica, ejercida está en su ámbito competencial, determinados preceptos del ordenamiento procesal general con la sola finalidad de dotar de sentido o inteligibilidad al texto normativo aprobado por el Parlamento autonómico» (STC 47/2004, de 25 de marzo, FJ 8).

En relación con las competencias compartidas, la consecuencia de la reproducción de la norma estatal en la autonómica no será siempre la inconstitucionalidad, sino que habrá que estar a los efectos que tal reproducción pueda producir en el caso concreto, que incluso puede llegar a ser conveniente para que se entienda la regulación autonómica que ensambla con la estatal a la que desarrolla.

La STC 51/2019 recuerda que la reiteración de la normativa estatal básica por el legislador autonómico, para ser admisible desde el punto de vista constitucional, debe satisfacer dos condiciones necesarias.

a) Por un lado, debe concurrir un elemento finalista que justifique la necesidad de esa reproducción, que solo podrá tener un sentido instrumental: hacer más comprensible el desarrollo normativo que realiza la comunidad autónoma en ejercicio de sus competencias propias. No sería por ello aceptable que la reproducción de las bases estatales pretendiese simplemente refundir en un único texto normativo toda la regulación aplicable en una materia (bases y desarrollo), aunque fuese con la intención de facilitar su uso al aplicador del derecho, porque daría la impresión equivocada de que el legislador autonómico ha asumido la competencia sobre la totalidad de una regulación, como si fuese autor de un sistema normativo completo, cuando en realidad está engarzado en el marco más amplio del ordenamiento del Estado, al que complementa. De hecho, en los casos en los que esa recepción instrumental de la normativa estatal sea posible, si bien la norma autonómica no queda formalmente alterada cuando la estatal se modifica, sí queda materialmente, e incurrirá en inconstitucionalidad sobrevenida si no se acomoda por el legislador autonómico al nuevo contenido de las bases tras su reforma. Aunque en ese caso, mientras el legislador autonómico no reaccione para acomodar su regulación a la modificación sobrevenida de la legislación básica estatal, el TC recuerda que ha admitido la posible inaplicación judicial del precepto legal autonómico desajustado a aquella en virtud de la regla constitucional de prevalencia del derecho estatal, recogida en el art. 149.3 CE 
b) Por otro lado, será también necesario, como condición material, que la reproducción de la normativa básica sea fiel y no incurra en alteraciones más o menos subrepticias de la misma, efecto que puede producirse bien por recogerla solo de modo parcial, bien por parafrasear la regulación estatal en términos que introduzcan confusión. En particular, el TC advierte que «omitir [una condición básica] puede ser en ocasiones tanto como contradecir», sobre todo «cuando a resultas de una omisión, sea parcial o completa, la norma autonómica contenga en sí misma y por consecuencia una regulación contraria a la ley básica estatal». En definitiva, el legislador autonómico no puede, con ocasión de su desarrollo, reformular las bases estatales, pretendiendo incidir en su eficacia en su territorio, sino que su recepción de la misma ha de ser, además de instrumental o auxiliar, fidedigna.

Es la referida doctrina la que lleva a la STC 51/2019 a declarar la inconstitucionalidad de un buen número de preceptos recogidos en la norma autonómica sobre educación por realizar una reproducción de la base estatal incompleta que induce a confusión sobre el contenido vigente de la base estatal en la materia, que fija de manera clara determinados conceptos, que pretenden ser sustituidos por una versión del legislador autonómico, que parece aportar una descripción propia e innecesaria del sentido recogido por el legislador estatal y que es más breve e incompleta.

Por tanto, todos aquellos preceptos autonómicos que realizan la reproducción reducida y en términos parcialmente diferentes de una normativa básica estatal mucho más detallada distorsionan el valor de una legislación básica que ha de ser respetada y, al ser innecesarios para dar sentido a un desarrollo autonómico que no existe en la norma examinada, resultan inconstitucionales. Aunque no se explicite en la STC 51/2019, se podría considerar que se vulnera en estos casos de reproducción no adecuada el principio de lealtad que exigiría que en el ejercicio de las competencias propias se sea respetuoso con el ámbito de decisión del otro nivel territorial.

3. La STC 7/2019, de 17 de enero, resuelve el recurso de inconstitucionalidad planteado por el presidente del Gobierno contra diversos artículos de la Ley del Parlamento de Cataluña 10/2017, de 27 de junio, de las voluntades digitales y de modificación de los libros segundo y cuarto del Código Civil de Cataluña.

El recurso de inconstitucionalidad tiene un fundamento exclusivamente competencial. Las partes discrepan en el entendimiento que tienen sobre la naturaleza jurídica — civil o administrativa - del registro electrónico de 
voluntades digitales creado por el art. 10 de la Ley 10/2017, en el que debe inscribirse el documento de voluntades digitales, en defecto de testamento, codicilo o memoria testamentaria.

El TC estima la impugnación por considerar que nos encontramos ante un registro jurídico de derecho privado, pues señala que de acuerdo con la Ley 10/2017, el documento de voluntades digitales es el medio por el que las personas avecindadas en Cataluña pueden disponer mortis causa de sus archivos digitales frente a los prestadores de servicios de la sociedad de la información, en defecto de testamento, codicilo o memoria testamentaria. En ese documento de voluntades digitales pueden designar a las personas físicas o jurídicas encargadas de ejecutar sus instrucciones al respecto, en cuyo caso deberán especificar el alcance concreto de la actuación de la persona designada. El documento de voluntades digitales previsto en la Ley 10/2017 ha de inscribirse, para su eficacia, en el registro creado por esa misma ley.

Ello es lo que lleva a la STC 7/2019 a señalar que es la inscripción del documento de voluntades digitales en el registro electrónico creado por la ley autonómica la que otorga eficacia jurídica a las previsiones del causante en orden a disponer mortis causa de sus voluntades digitales, del mismo modo que si las hubiera manifestado por medio de testamento, codicilo o memoria testamentaria, en defecto de estas.

Por tanto, la STC 7/2019 declara la inconstitucionalidad y nulidad del art. 10 de la Ley 10/2017 —y de otros preceptos por conexión-, en cuanto crea un registro jurídico de derecho privado, que solo puede ser establecido por el Estado, al amparo de su competencia exclusiva en materia de ordenación de los registros e instrumentos públicos (art. 149.1.8 CE).

La STC 7/2019 cuenta con un voto particular de la vicepresidenta Roca Trías en el que la misma considera que la sola inscripción del documento de voluntades digitales en el referido registro no determina la naturaleza jurídico-civil de mismo. Argumenta que la existencia de un registro público no impide que puedan existir otros tipos de disposiciones de última voluntad puramente privados, como los testamentos, codicilos y memorias testamentarias otorgados en forma ológrafa que poseen igual validez que los inscritos.

Para la magistrada discrepante son numerosos los actos y negocios jurídicos civiles susceptibles de inscripción en los registros y no por ello tales registros gozan de naturaleza civil, sino que pueden tenerla administrativa. Así sucede, por ejemplo, con los distintos registros de las parejas de hecho, para las que el art. 174 de la Ley general de la Seguridad Social exige su inscripción para el reconocimiento de las pensiones de viudedad; o con el propio registro de actos de última voluntad, cuyo funcionamiento carece de los requisitos connaturales a los registros civiles a los que se refiere el art. 149.1.8 CE, 
pues entre otras cosas, solo publicita o da a conocer la existencia o inexistencia de tales voluntades, pero no declara o reconoce derechos subjetivos de algún tipo, ni existe función calificadora alguna del registrador en orden al control de legalidad del acto de inscripción en su condición de funcionario público del registro. Para la magistrada discrepante, que el objeto de un registro sean «las relaciones privadas» no determina que el mismo tenga naturaleza civil.

Por otra parte, considera que la ley catalana no faculta al causante para decidir sobre el destino de sus bienes digitales. En efecto, el documento de voluntades digitales al que se refiere la norma impugnada no contendría una verdadera ordenación de la sucesión, tan siquiera de los materiales o archivos digitales del causante, que con independencia del soporte digital en el que se encuentran, en todo caso forman parte del caudal hereditario y son objeto de la sucesión. Lo que en realidad recoge el documento es la voluntad del fallecido respecto a la realización de actividades muy concretas que están directamente relacionadas con el ejercicio de derechos personalísimos de carácter no patrimonial, por tanto, no transmisibles mortis causa, como las de comunicar a los prestadores de servicios digitales su defunción; solicitar la cancelación de las cuentas activas o que ejecuten las cláusulas contractuales o que se activen las políticas establecidas para los casos de defunción y, en su caso, que libren una copia de los archivos digitales que estén en sus servidores.

El voto particular considera que por las razones expuestas el recurso debió ser desestimado.

4. En el periodo de tiempo examinado en la presente crónica se han producido igualmente diversos pronunciamientos del TC en relación con impugnaciones de distintos impuestos autonómicos por parte del Gobierno por considerar que los mismos gravaban el mismo hecho imponible que determinados impuestos estatales o locales. La crisis económica y la necesidad de cumplir con los principios de estabilidad presupuestaria y sostenibilidad financiera han propiciado que algunas comunidades autónomas, más allá de promover el cumplimiento de aquellos mediante la realización de recortes en materia de gastos, hayan tratado de adoptar medidas que aumentasen sus ingresos y con las cuales, además, se alcanzasen determinadas finalidades extrafiscales como puede ser promover la función social de la propiedad. El Estado, sin embargo, se ha mostrado poco sensible a tales medidas impositivas y las ha impugnado sistemáticamente. El TC, sin embargo, ha desestimado algunas de tales impugnaciones por no apreciar la existencia de doble imposición.

a) Así ocurre, por ejemplo, en la STC 4/2019, de 17 de enero, en la que se desestima el recurso de inconstitucionalidad interpuesto por el 
presidente del Gobierno contra determinados artículos de la Ley del Parlamento de Cataluña 14/2015, de 21 de julio, del impuesto sobre las viviendas vacías por vulnerar el art. 6.3 de la Ley Orgánica 8/1980, de 22 de septiembre, de financiación de las comunidades autónomas, en relación con los tributos locales, y, específicamente, con el impuesto sobre bienes inmuebles (IBI).

El TC recuerda la finalidad de la modificación del art. 6.3 LOFCA llevada a cabo por la Ley Orgánica 3/2009, de 18 de diciembre, que no fue otra que ampliar el espacio fiscal de las comunidades autónomas respecto de los tributos locales, sustituyendo el límite basado en la «materia imponible» por el referido al "hecho imponible», a semejanza de lo que venía haciendo, sin cambios desde su redacción original, el art. 6.2 LOFCA, en relación con los tributos estatales.

Una vez recordado el sentido de la reforma de 2009, el TC insiste en que para apreciar la coincidencia entre hechos imponibles, que es lo vedado por los apdos. segundo y tercero del art. 6 LOFCA, se hace preciso atender a los elementos esenciales de los tributos que se confrontan, al objeto de determinar la «manera» en que la correspondiente fuente de capacidad económica es sometida a gravamen en la estructura del tributo. Para lo cual se habrá de analizar, además del hecho imponible en sentido estricto, otros aspectos como los supuestos de no sujeción y exención, el sujeto pasivo y los elementos de cuantificación. Asimismo, entre los elementos a comparar se encuentra la posible concurrencia de fines extrafiscales en el conjunto del tributo o en alguno de sus elementos centrales.

En aplicación del canon expuesto, el TC procede a realizar el contraste entre el impuesto autonómico sobre las viviendas vacías recogido en la Ley 14/2015, de 21 de julio, y el impuesto sobre bienes inmuebles (IBI), para así dilucidar si aquel recae sobre el mismo hecho imponible gravado por este.

Tras sintetizar los elementos definidores de cada figura, aborda el examen comparativo que demanda el art. 6.3 LOFCA.

Frente al IBI que recae sobre la titularidad de toda clase de inmuebles, rústicos o urbanos (y dentro estos, tanto viviendas, como garajes, oficinas, naves, almacenes, etc.), en el impuesto autonómico sobre las viviendas vacías tributan solo las viviendas, y no todas, sino tan solo las que llevan desocupadas durante un determinado tiempo y sin razón que lo justifique (según las causas tasadas por la ley autonómica). Además, señala el TC, el IBI es un gravamen real en el que cada inmueble tributa por separado, sin tener en cuenta el número de 
inmuebles de un mismo titular, mientras que el impuesto sobre las viviendas vacías es personal, por cuanto atiende a la superficie total de vivienda desocupada de que es titular el sujeto pasivo. La desocupación de la vivienda - y no su mera titularidad — se convierte así en la verdadera razón del gravamen autonómico, concebido como un instrumento para que aumente la oferta de viviendas en alquiler, de modo que no se grava la propiedad per se, sino "por el hecho de permanecer desocupadas de forma permanente».

Por su parte, las exenciones del impuesto sobre las viviendas vacías también conectan con la finalidad proclamada, ya que se dejan sin gravamen las viviendas situadas en zonas de escasa demanda acreditada y las puestas a disposición de programas de alquiler social, entre otras.

El ámbito subjetivo de los dos tributos no es el mismo ya que el impuesto catalán solo recae sobre personas jurídicas, en tanto que el IBI también grava a las personas físicas y entidades sin personalidad. El modo de cuantificación de ambos tributos también difiere de forma sustancial. La base imponible del IBI es el valor catastral, que se calcula no en atención a la ocupación o desocupación, sino a partir de características ínsitas al inmueble, como su localización, calidad constructiva y antigüedad. Por el contrario, la base imponible del impuesto autonómico es una unidad física: los metros cuadrados de superficie desocupada, sin atender a otras características del inmueble más que su desocupación, ya que lo relevante para satisfacer la necesidad de vivienda es la superficie en sí y no su valor. También son distintas las bonificaciones de ambos impuestos

La recaudación del impuesto sobre las viviendas vacías está afectada a actuaciones en materia de vivienda en los municipios donde se sitúan las viviendas desocupadas, lo que no sucede en el IBI.

Por último, los impuestos contrastados no tienen la misma finalidad, ya que el impuesto sobre las viviendas vacías es fundamentalmente extrafiscal; en concreto, pretende incentivar la puesta en alquiler de viviendas desocupadas. En cambio, el IBI es principalmente fiscal, sin perjuicio de que algunos de los elementos que modulan la carga tributaria se establezcan en función de criterios extrafiscales, siempre con carácter secundario.

En suma, concluye el TC que entre el impuesto sobre las viviendas vacías y el IBI se aprecian diferencias sustanciales, que llevan a concluir que no estamos ante tributos «coincidentes» ni «equivalentes» a efectos del art. 6.3 LOFCA. 
La conclusión alcanzada considera el TC que no queda enervada por la circunstancia de que el art. 72.4 de la Ley de Hacienda Locales (LHL) prevea un recargo en el IBI para viviendas desocupadas.

En efecto, el art. 72.4 LHL prevé la posibilidad de que los ayuntamientos que así lo decidan apliquen un recargo a los «inmuebles de uso residencial que se encuentren desocupados con carácter permanente». Sin embargo, considera el TC que el legislador estatal no ha concebido el recargo como una figura independiente del IBI, sino como uno de los factores relevantes para su cuantificación, lo que le lleva a descartar que pueda considerarse como un hecho imponible autónomo a efectos de la prohibición del art. 6.3 LOFCA, que veda a los tributos propios de las comunidades autónomas «recaer sobre hechos imponibles gravados por los tributos locales» y no otra cosa.

Para el TC el carácter accesorio del recargo previsto en el art. 72.4 LHL se confirma por el hecho de que, pese a haberse introducido por la Ley 51/2002, de 27 de diciembre, es decir hace diecisiete años, el mismo no ha sido aplicado hasta la fecha, al no haberse desarrollado por el Estado el concepto de «inmuebles de uso residencial que se encuentren desocupados con carácter permanente» como exigía el art. 72.4, párr. tercero, LHL antes de su reciente modificación por el Real Decreto Ley 21/2018, de 14 de diciembre. Y con mayor motivo cabe descartar la extralimitación competencial a la vista de que la nueva redacción ya no reserva al Estado la definición de dicho concepto.

Para el TC el impuesto sobre las viviendas vacías de Cataluña recae sobre la misma «materia» que el IBI (incluido el recargo del art. 72.4 LHL), pues grava inmuebles que también están sujetos al impuesto local, pero ambos tienen un hecho imponible distinto por lo que el recurso es desestimado.

b) Igualmente, la STC 28/2019, de 28 de febrero, desestima, el recurso de inconstitucionalidad interpuesto por el presidente del Gobierno contra determinados preceptos de la Ley del Parlamento de Cataluña 6/2017, de 9 de mayo, del impuesto sobre los activos no productivos de las personas jurídicas.

Para resolver la controversia planteada, el TC aplica nuevamente la consolidada doctrina sobre los límites del poder tributario de las comunidades autónomas recogidos en los apdos. 2 y 3 del art. 6 LOFCA, en virtud de los cuales los tributos que establezcan las comunidades autónomas no podrán recaer sobre hechos imponibles gravados por el Estado (apdo. 2) —en este el impuesto estatal de contraste 
era el impuesto sobre el patrimonio — ni podrán recaer sobre hechos imponibles gravados por los tributos locales (apdo 3) —en el supuesto impugnado los impuestos locales a contrastar eran los impuestos sobre bienes inmuebles y sobre vehículos de tracción mecánica-.

En lo que se refiere al contraste del tributo autonómico controvertido con el impuesto estatal sobre el patrimonio, para determinar la vulneración del art. 6.2 LOFCA, el TC señala en primer lugar la diferencia entre los sujetos gravados, pues el tributo autonómico grava a las personas jurídicas y el impuesto estatal solo a las personas físicas

Junto al elemento subjetivo, el impuesto sobre los activos no productivos y el impuesto sobre el patrimonio se diferencian además por el propósito con que cada uno grava la titularidad de bienes y derechos. Así, recuerda el TC que el supuesto se planteó igualmente al contrastar en su momento el impuesto sobre el patrimonio con el impuesto andaluz sobre tierras infrautilizadas, de finalidad análoga al tributo catalán aquí enjuiciado, cuando el TC puso de manifiesto que los hechos imponibles que ambas normas contemplaban eran notoriamente distintos porque era obvio que no cabía identificar la «infrautilización» de fincas rústicas — hecho imponible del impuesto andaluz- con la «propiedad» de todo tipo de bienes, aunque entre ellos se encuentren las fincas rústicas, que es el hecho que grava el impuesto estatal (STC 37/1987, de 26 de marzo, FJ 14).

Asimismo, seńala el TC como un criterio relevante para valorar la posible superposición de un tributo autonómico con los tributos estatales o locales es la finalidad predominantemente fiscal o extrafiscal de las figuras en liza. En el caso de la norma autonómica impugnada el fin es fomentar la función social de la propiedad, en este caso, de los activos improductivos de las entidades mercantiles. Dicha finalidad enlaza directamente con "principios establecidos e intereses tutelados en la misma Constitución como son los arts. 40.1, 128.1 y $130.1 \mathrm{CE}$ pues una medida que estimule la explotación de los activos de las entidades mercantiles se inscribe en los objetivos de política económica que proclaman dichos preceptos».

El examen de los elementos estructurales del impuesto sobre los activos no productivos corrobora su finalidad extrafiscal, toda vez que los activos relacionados en la Ley 6/2017 solo se gravan en tanto en cuanto no sean productivos, lo que sucede cuando permanecen ajenos al objeto de la entidad mercantil.

Se comprueba así que el impuesto autonómico sobre los activos no productivos no grava todos los activos de las entidades mercantiles, en 
tanto que expresivos de capacidad económica, lo que sería propio de un tributo con fines primordialmente recaudatorios, como el impuesto sobre el patrimonio, sino únicamente los improductivos, de tal manera que si los bienes se afectan a una actividad económica el gravamen deja de ser exigible, por haberse logrado el propósito de la medida.

Por tanto, el TC concluye que, además de por su ámbito subjetivo, el impuesto sobre los activos no productivos y el impuesto sobre el patrimonio se diferencian también por su finalidad, lo que lleva a excluir que tengan el mismo hecho imponible en los términos del art. 6.2 LOFCA.

En lo que se refiere al contraste del tributo autonómico controvertido con los impuestos locales sobre bienes inmuebles y sobre vehículos de tracción mecánica para determinar la vulneración del art. 6.3 LOFCA, el TC considera que la conclusión sobre el carácter extrafiscal del impuesto sobre los activos no productivos a que ha llegado al examinar la compatibilidad del tributo con el impuesto estatal de patrimonio es relevante también a la hora de valorar la denuncia de vulneración del art. 6.3 LOFCA, toda vez que, aunque el tributo autonómico recaiga sobre bienes también gravados por tributos locales, lo hace en atención a una circunstancia distinta, que es su improductividad.

Así, aun cuando el impuesto sobre los activos no productivos también recaiga sobre los inmuebles que pertenecen a las entidades mercantiles, únicamente lo hace en la medida en que se mantienen improductivos, por lo que su hecho imponible es la falta de explotación de los inmuebles y no la capacidad de pago que revela su titularidad, como en el IBI. El impuesto sobre los activos no productivos responde así a la misma ratio que el impuesto sobre las viviendas vacías regulado en la Ley del Parlamento de Cataluña 14/2015, que tiene muchos elementos en común con el impuesto ahora enjuiciado, en concreto, su finalidad primordialmente extrafiscal, y cuya colisión con el IBI el TC ha descartado en la STC 4/2019 (FJ 5), a la que nos hemos referido en esta misma crónica.

A la distinta finalidad de ambas figuras se añaden otras diferencias relevantes, que también había advertido el TC en relación con el impuesto sobre las viviendas vacías. Así, el impuesto sobre los activos no productivos es un impuesto personal que grava acumuladamente todos los bienes y derechos improductivos del sujeto pasivo, frente al IBI que es un tributo de carácter real (art. 60 LHL). En conexión con 
lo anterior, el impuesto catalán se cuantifica por medio de una tarifa progresiva de gravamen (art. 8 de la Ley 6/2017), aplicable sobre el conjunto de activos improductivos de la persona jurídica (valorados según dispone el art. 7 de la ley), en tanto que el tipo de gravamen del tributo local es proporcional (art. 72 LHL), al recaer sobre cada inmueble aisladamente considerado.

Por su parte el otro impuesto local de contraste, el impuesto sobre vehículos de tracción mecánica (IVTM), grava la titularidad del vehículo como índice de capacidad de pago, mientras que el impuesto sobre los activos no productivos lo hace porque la entidad mercantil no lo explota económicamente y solo mientras esa situación se mantenga.

A lo anterior se suma que el IVTM — también de naturaleza real como el IBI- se cuantifica mediante unas cuotas por tipo de vehículo (no tiene base imponible a la que se aplique un tipo de gravamen) que establece el art. $95 \mathrm{LHL}$, en función de la potencia del vehículo, como índice de la capacidad de pago. Esto contrasta de nuevo con el impuesto sobre los activos no productivos en el que los vehículos gravados, que son únicamente los de potencia superior a 200 caballos no afectos a una actividad económica, tributan acumuladamente junto al resto de bienes improductivos de su titular, a través de una tarifa progresiva que se aplica al valor total del patrimonio improductivo.

En suma, considera la STC 28/2019 que entre el impuesto catalán enjuiciado y los dos tributos locales invocados en la demanda se aprecian diferencias sustanciales, que llevan a concluir que no estamos ante tributos "coincidentes» (STC 210/2012, de 14 de noviembre, FJ 6) ni «equivalentes» (STC 53/2014, de 10 de abril, FJ 3) tampoco a efectos del art. 6.3 LOFCA.

La STC 28/2019 finalmente rechaza que el impuesto autonómico sobre los activos no productivos vulnere el art. 157.2 CE que prohíbe a las comunidades autónomas «adoptar medidas tributarias sobre bienes situados fuera de su territorio»; o el art. 9 LOFCA que desarrolla el anterior y según el cual las comunidades autónomas podrán establecer sus propios impuestos, respetando, el límite de no sujetar «elementos patrimoniales situados, rendimientos originados ni gastos realizados fuera del territorio de la respectiva comunidad autónoma». El TC considera que el impuesto sobre los activos no productivos no provoca efectos extraterritoriales por el hecho de incluir en su base imponible todos los vehículos improductivos de las entidades 
domiciliadas en Cataluña, al margen de su ubicación en cada momento, ya que, a efectos fiscales, tales vehículos se consideran localizados en el territorio de dicha comunidad.

c) Al contrario que las dos anteriores impugnaciones, la STC 43/2019, de 27 de marzo, estima parcialmente el recurso de inconstitucionalidad, interpuesto por el presidente del Gobierno contra determinados preceptos de la Ley del Parlamento de Cataluña 5/2017, de 28 de marzo, de medidas fiscales, administrativas y del sector público y de creación y regulación de los impuestos sobre grandes establecimientos comerciales, sobre estancias en establecimientos turísticos, sobre elementos radiotóxicos, sobre bebidas azucaradas envasadas y sobre emisiones de dióxido de carbono.

Los preceptos impugnados se refieren, de una parte, a una modificación de la base imponible del impuesto sobre las viviendas vacías (art. 4.1), y de otra, a la creación del impuesto sobre el riesgo medioambiental de la producción, manipulación y transporte, custodia y emisión de elementos radiotóxicos.

En relación con la impugnación del precepto referido al impuesto sobre viviendas vacías, el recurso es desestimado al considerar el TC que el recurrente no ha aportado argumentos de inconstitucionalidad específicamente referidos a este precepto, no obstante lo cual la STC 43/2019 recuerda que el impuesto al que se refiere ya fue examinado en su configuración misma en el proceso resuelto por la citada STC 4/2019.

Sin embargo, en cuanto a la parte de la norma referida al impuesto sobre elementos radiotóxicos el mismo es declarado inconstitucional por la STC 43/2019 en la línea marcada por la STC 74/2016, de 14 de abril, referida a un impuesto a la producción de energía eléctrica de origen nuclear.

El objeto del impuesto autonómico consiste en «gravar el riesgo local medioambiental, y en última instancia sobre las personas, que comporta, en el territorio de Cataluńa, la producción de elementos radiotóxicos generados en reacciones termonucleares; la manipulación y el transporte de estos elementos; su custodia, mientras no sean debidamente neutralizados o depositados en un almacén de larga duración, y su dispersión, rutinaria o accidental».

Los impuestos estatales de contraste se encuentran recogidos en la Ley 15/2012, de 27 de diciembre, de medidas fiscales para la sostenibilidad energética, que prevé, por una parte el denominado impuesto sobre la producción de combustible nuclear gastado y residuos radiactivos resultantes de la generación de energía nucleoeléctrica y el 
impuesto sobre el almacenamiento de combustible nuclear gastado y residuos radiactivos en instalaciones centralizadas y por otro el denominado impuesto sobre el almacenamiento de combustible nuclear gastado y residuos radiactivos en instalaciones centralizadas.

La STC 43/2019 considera que los elementos regulatorios esenciales de los impuestos contrastados permiten concluir que existe equivalencia entre los mismos, pues con independencia de los términos técnicos con que se configuran, los tributos recaen sobre la misma materia imponible o fuente de capacidad económica, que no es otra que la producción de energía eléctrica en una central nuclear, haciéndolo además desde la misma perspectiva: gravar las externalidades negativas que supone la energía nuclear, medidas por los riesgos que ésta comporta.

Para el TC el dato clave para llegar a esta conclusión sobre la identidad de los impuestos examinados es que los elementos definidos en el hecho imponible del impuesto autonómico sobre elementos radiotóxicos no tienen sustantividad propia, sino que son parte del proceso de producción de energía eléctrica en una central nuclear, encontrándose así en una necesaria relación de instrumentalidad con respecto a ese fin principal. Esto es, ninguno de ellos se puede producir por sí mismo, con independencia de los demás, sino que forman parte de un continuum o proceso. De esta manera, todo proceso de fisión genera desintegraciones y se produce a su vez a partir del combustible nuclear que, posteriormente, será combustible gastado y que, lógicamente, deberá antes haber sido producido, manipulado, transportado, custodiado de forma transitoria, dando lugar, en fin, a la correspondiente emisión de elementos radiotóxicos al medioambiente. Es decir, los hechos imponibles expuestos en el art. 54 de la Ley 5/2017 no vienen más que a describir el proceso mismo de producción de energía nuclear, deslindando sus fases a los únicos efectos de construcción de un tributo que se pretende distinto del estatal ya existente ${ }^{29}$.

\section{ORGANIZACIÓN DE LOS PODERES PÚBLICOS}

1. La doctrina sentada en las SSTC 34/2018 (Pleno), de 12 de abril, y $44 / 2018$ (Pleno), de 26 de abril ${ }^{30}$, en relación con el veto presupuestario del

29 Tomás de la Quadra-Salcedo Janini.

30 Reseñadas en la Revista Española de Derecho Constitucional, núm. 113, 2018, pp. 261-264. 
Gobierno a la tramitación de iniciativas legislativas que impliquen aumento de créditos o disminución de ingresos presupuestarios (art. 134.6 CE), se ha proyectado una vez más, durante el periodo considerado en la presente crónica, en un recurso de amparo parlamentario, resuelto por la STC 17/2019 (Sala Segunda), de 11 de febrero.

La STC 17/2019 estima el recurso de amparo parlamentario interpuesto contra los acuerdos de la Mesa del Congreso de los Diputados que, con aceptación del criterio del Gobierno, resolvieron la no procedencia de someter a toma en consideración por el Pleno del Congreso una proposición de ley relativa a la modificación del texto refundido de la Ley del Estatuto de los Trabajadores, «al objeto de fortalecer la negociación colectiva en la regulación de las relaciones laborales», presentada por el grupo parlamentario recurrente. Aplicando la doctrina sentada en las SSTC 34/2018 y 44/2018, y como ya sucediera también en las SSTC 94/2018 (Sala Segunda), de 17 de septiembre, y 139/2018 (Sala Primera), de 17 de diciembre, que estiman sendos recursos de amparo parlamentario referidos al veto presupuestario ${ }^{31}$, la STC 17/2019 declara que los acuerdos impugnados han vulnerado el derecho de participación política de los diputados recurrentes, porque la aplicación de la facultad de veto del Gobierno, asumida por el órgano parlamentario, se ha fundamentado en la aplicación extensiva de la facultad de veto del art. 134.6 CE, proyectándola «a supuestos que van más allá en el tiempo del marco del presupuesto anual», a lo que se añade que el pronóstico que sobre el aumento de los créditos realiza el Gobierno (y asume el órgano parlamentario) carece de fundamentación objetiva, pues no establece la relación directa entre las medidas de la proposición de ley y las concretas partidas presupuestarias de gastos que se verían afectadas, por lo que, en consecuencia, incumple con los requisitos de motivación establecidos en las citadas SSTC 34/2018 y 44/2018, pues «no ofrece respuesta a los concretos argumentos dados por el grupo parlamentario acerca de que la iniciativa legislativa no supone un aumento de los créditos presupuestarios» (FJ 4).

2. La relevante STC 19/2019 (Pleno), de 12 de febrero, resuelve la impugnación de disposiciones autonómicas formulada por el Gobierno de la Nación en relación con la propuesta del presidente del Parlamento de Cataluña de investir como presidente del Gobierno de la Generalitat a un diputado prófugo.

Como un episodio más del desafío separatista al Estado de derecho, tras las elecciones al Parlamento de Cataluña de 21 de diciembre de 2017, el presidente de la asamblea legislativa autonómica pretendió celebrar la sesión de

31 Reseñadas en la Revista Española de Derecho Constitucional, núm. 115, 2019, pp. $285-286$. 
investidura del presidente del Gobierno de la Generalitat en ausencia del candidato propuesto al efecto, huido de la justicia. Las medidas cautelares adoptadas por el TC en su ATC 5/2018, de 27 de enero (confirmado por ATC 6/2018, de 30 de enero), antes de decidir sobre la admisión de la impugnación de esa decisión parlamentaria por el Gobierno de la Nación (finalmente la admisión se produjo por ATC 49/2018, de 26 de abril, confirmado por ATC 60/2018, de 5 de junio) ${ }^{32}$, propiciaron sin duda (así lo aprecia la STC 19/2019, FJ 7) que el presidente de la Cámara autonómica desistiese de su designio inicial, ya que, antes incluso de que se admitiese a trámite la impugnación, procedió a convocar nueva sesión de investidura, proponiendo nuevo candidato (este en prisión provisional); como es sabido, tras la investidura fallida de este candidato, y del propuesto a continuación, finalmente se produjo con éxito (de procedimiento, entiéndase), la investidura del candidato para el cargo de presidente de la Generalitat de Cataluña. Conforme señala la STC 19/2019 (FJ 2), corroborando lo que ya había apreciado el TC en su ATC 49/2018 (FJ 1), esta circunstancia sobrevenida determina que la decisión impugnada por el Gobierno de la Nación (la propuesta de investir a un prófugo) carezca de eficacia, sin que ello suponga la pérdida de objeto del proceso constitucional, dadas las cuestiones de interés general que en él se plantean ${ }^{33}$.

En efecto, esa impugnación ha dado al TC la oportunidad de pronunciarse de manera contundente en la STC 19/2019 sobre la inconstitucionalidad de cualquier decisión de un presidente de una asamblea legislativa que pretenda llevar a cabo la investidura del presidente del Ejecutivo en ausencia del candidato propuesto.

La investidura telemática o por sustitución no es constitucionalmente admisible: el candidato a presidente de la Generalitat debe comparecer personalmente ante la Cámara para defender su programa de gobierno y solicitar su confianza. Esta exigencia, aunque no se establezca expresamente en la Constitución ni en el Estatuto de Autonomía de Cataluña (EAC), se encuentra implícita en bloque de la constitucionalidad; así lo imponen, por una parte, la naturaleza parlamentaria de este procedimiento y, por otra, la propia configuración del procedimiento de investidura. El ejercicio de las funciones representativas ha de

32 Los AATC 5/2018, 6/2018 y 49/2018 fueron reseñados en Revista Española de Derecho Constitucional, núm. 113, 2018, pp. 230-232.

33 Por el contrario, esa misma circunstancia determina, conforme a la STC 52/2019 (Pleno), de 11 de abril, la pérdida sobrevenida de objeto del recurso parlamentario interpuesto contra la decisión del presidente del Parlamento de Cataluńa de posponer sine die la convocatoria de la sesión de investidura, no presencial, del candidato que había propuesto a la presidencia de la Generalitat, el expresidente huido de la Justicia. 
desarrollarse, como regla general, de forma personal y presencial, pues ello constituye una garantía del correcto ejercicio del derecho de participación política. Y en particular la naturaleza del acto de investidura del presidente del Ejecutivo «exige que este procedimiento no pueda celebrarse sin la presencia en la cámara del candidato", acudiendo a la sede del Parlamento. La actuación del candidato en la sesión de investidura (la presentación de su programa de gobierno y la solicitud de la confianza, así como la intervención en el debate) tiene carácter personalísimo. El procedimiento de investidura exige que sea el propio candidato el que defienda su programa, pues la Cámara no otorga su confianza a un programa de gobierno, sino a un candidato. No cabe, por tanto, que otro diputado pueda sustituirle ni actuar en su nombre en este procedimiento. Tampoco cabe admitir una intervención del candidato «a distancia», a través de medios telemáticos, pues ello menoscabaría el correcto desarrollo del procedimiento de investidura; en suma, «una comparecencia telemática no equivale a una comparecencia presencial», y «el procedimiento parlamentario, expresión de la democracia misma, exige interacción entre presentes» (FJ 4).

Se añade a lo anterior que la exigencia de que la investidura tenga lugar precisamente en la sede del Parlamento no solo atiende a garantizar que los parlamentarios puedan ejercer su función representativa en un lugar en el que no puedan ser perturbados, sino que cumple también una función simbólica, pues hace visible la posición de sometimiento del candidato a la voluntad del pueblo representado por el Parlamento (FJ 5).

Por todo ello, el TC concluye que una investidura en la que el candidato no compareciera presencialmente ante la Cámara para solicitar su confianza sería contraria al bloque de la constitucionalidad, al vulnerar los principios que derivan del art. 99.2 CE (y en el caso examinado también del art. 67 EAC y del art. 149 del Reglamento de Parlamento de Cataluña). Además, la investidura no presencial comportaría una vulneración de los derechos de los parlamentarios que consagra el art. 23.1 CE (FFJJ 5 y 6).

La aplicación de la doctrina sentada en la STC 19/2019 dará lugar a la estimación, por la STC 45/2019 (Pleno), de 27 de marzo, del recurso de inconstitucionalidad interpuesto por el presidente del Gobierno respecto de diversos preceptos de la Ley del Parlamento de Cataluńa 2/2018, de 8 de mayo, que posibilitan la investidura no presencial del candidato a la presidencia de la Generalitat, así como la celebración de reuniones a distancia del Consejo de Gobierno. El TC advierte que la relación de confianza que debe existir entre Gobierno y Cámara legislativa es elemento característico del sistema parlamentario representativo diseñado por la Constitución de 1978. Esa relación fiduciaria, con las consiguientes facultades de control parlamentario sobre la acción de gobierno, «no se cohonesta con una regulación que permite 
celebrar una sesión de investidura de la presidencia de la Generalitat en la que el candidato no comparezca o no intervenga ante la cámara para obtener la confianza de esta» (FJ 3). Se declara en consecuencia inconstitucional y nulo el precepto que pretendía dar cobertura legal a la investidura no presencial del presidente de la Generalitat de Cataluña, pues el acto de investidura del candidato a la presidencia de la Generalitat exige, en todo caso, su intervención personal y presencial, como ya había declarado la citada STC 19/2019 (FJ 4).

Examina seguidamente el TC en qué medida la previsión contenida en la ley impugnada de que el Gobierno de la Generalitat pueda celebrar sesiones tanto de forma presencial como a distancia respeta su naturaleza como órgano colegiado de dirección política, según lo configuran la Constitución y el Estatuto de Autonomía. Advierte en tal sentido el TC que «el carácter deliberativo de las sesiones del Gobierno es consustancial a la naturaleza de las decisiones que se adoptan en aquellas» (FJ 5), de lo que se infiere la singularidad del Gobierno como órgano colegiado, lo que excluye que se le puedan trasladar, sin más, las reglas generales sobre uso de medios telemáticos previstas para los órganos colegiados «administrativos», como hace la ley impugnada. Por tanto, concluye el TC, habrá actuaciones, como la remisión de la documentación preparatoria, las convocatorias o las actas, en las que el uso de medios telemáticos por el Gobierno no plantee ninguna objeción desde la óptica constitucional; en cambio, para aquellas otras que constituyen el núcleo de su función, como es la forma de celebrar las sesiones, deliberar y adoptar acuerdos, la conclusión no puede ser la misma: estas actuaciones requieren de la actuación de forma presencial, necesaria para que el Gobierno pueda formar debidamente su voluntad. No cabe pues la celebración de reuniones a distancia del Consejo de Gobierno de la Generalitat. En consecuencia, se declara inconstitucional y nulo el precepto impugnado, en cuanto permite la constitución, celebración de sesiones y adopción de acuerdos por el Gobierno de la Generalitat por vía telemática, por vulnerar el art. 68.1 EAC, en conexión con los arts. 10 y 67.8 EAC. En cambio, ninguna tacha merece para el TC la previsión legal de que para «convocar» $\mathrm{y}$ «remitir actas» se empleen medios telemáticos, dado que se trata de funciones puramente documentales que no implican deliberación ni toma de acuerdos (FJ 6) ${ }^{34}$.

\section{DERECHOS FUNDAMENTALES}

1. El TC ha tenido una nueva ocasión para pronunciarse sobre la utilización de las cámaras ocultas en el ejercicio del periodismo. En la STC

34 Herminio Losada González. 
25/2019 (Sala Primera), de 25 de febrero ${ }^{35}$, los recurrentes aducían la vulneración por el Tribunal Supremo de sus derechos fundamentales al honor, a la intimidad personal y a la propia imagen (art. 18.1 CE). La controversia central planteada en el recurso de amparo versaba sobre el conflicto entre el derecho a comunicar libremente información veraz de un medio de comunicación y los derechos fundamentales al honor, a la intimidad personal y a la propia imagen del demandante de amparo, sobre el cual una cadena televisiva emitió diversos programas que combinaban el reportaje, el debate y la voz en off y que utilizaban imágenes captadas mediante cámara oculta en su consulta profesional por unos periodistas que se hicieron pasar por clientes interesados en sus servicios. Recuerda el TC que la CE excluye, por regla general, la utilización periodística de la cámara oculta, en cuanto que constituye una grave intromisión ilegítima en los derechos fundamentales a la intimidad personal y a la propia imagen; afirma, no obstante, que su utilización podrá excepcionalmente ser legítima cuando no existan medios menos intrusivos para obtener la información y que la justificación constitucional de la libertad de información, en todo caso, solo alcanza a la información de relevancia pública, que constituye su límite inmanente; asimismo, como regla general recuerda que los medios de comunicación social que difundan imágenes obtenidas mediante cámara oculta deberán distorsionar el rostro y la voz de las personas grabadas cuando su identificación no sirva al interés general en la información y que tampoco podrán difundirse imágenes que muestren situaciones o comportamientos que menoscaben innecesariamente la reputación de las personas. La sentencia impugnada fundamentó la prevalencia de la libertad de información de la cadena televisiva sobre el derecho a la intimidad del demandante de amparo en la veracidad de la información divulgada y su elevado interés informativo. El TC entiende que al considerar exclusivamente ambos factores el Tribunal Supremo no ponderó adecuadamente los derechos en conflicto. Por lo que respecta al primer factor, el TC viene reiterando que, cuando se afecta al derecho a la intimidad, lo determinante para resolver el conflicto de derechos es la relevancia pública de la información y no la veracidad del contenido de la información divulgada, en cuanto que, a diferencia de lo que sucede en las intromisiones en el honor, la veracidad no es paliativo sino presupuesto de la lesión de la intimidad. Por lo que respecta al segundo factor, comparte el criterio del Tribunal Supremo de que la finalidad de los reportajes y programas televisivos era difundir información de interés general, pues pretendía alertar sobre prácticas fraudulentas e intrusivas en el ámbito de la salud, con independencia de si consiguieron o no contribuir efectivamente a un

35 Véanse supra pp. 226-227 y 232. 
debate de interés general. No obstante, considera el TC que esa finalidad se desnaturalizó desde el momento en que se centró en la actuación de la concreta persona del demandante de amparo, sin que tampoco el propio material obtenido y difundido con la grabación clandestina permitiera concluir de forma contundente que estaba realizando prácticas claramente intrusivas. Recuerda la sentencia que no debe confundirse el interés general de un debate en abstracto con la relevancia pública de la concreta información divulgada; tampoco la curiosidad alimentada por el medio de comunicación, al atribuir un valor noticioso a la publicación de las imágenes objeto de controversia, debe ser confundida con un interés público digno de protección constitucional. En las imágenes difundidas no se muestran prácticas fraudulentas o conductas ilícitas en relación con el demandante de amparo. Al centrarse los programas televisivos en la persona del demandante de amparo y difundir un material insuficientemente concluyente de por sí y escasamente relevante para contribuir a un debate general, la intromisión en su intimidad no solo careció del, en principio, necesario consentimiento previo del titular del derecho para realizar la videograbación en la consulta profesional, sino que, en las circunstancias del caso, su divulgación constituyó también un ejercicio desproporcionado de la libertad de información. No puede olvidarse, recuerda el TC, la circunstancia de que la información fuera captada subrepticiamente en un ámbito privado como es una consulta profesional, en cuyo seno se desarrollan relaciones de naturaleza profesional que están también protegidas por el derecho a la intimidad, y en las que, por consiguiente, existe igualmente una legítima expectativa de resguardo frente a la intromisión de terceros. Por último, el recurso de amparo es estimado también con respecto a la vulneración alegada del derecho al honor, si bien no por la utilización de la cámara oculta ni por la difusión de las imágenes así obtenidas, sino por la forma en que se presentó la información y las afirmaciones que realizaron en los programas televisivos.

2. También con la libertad de información en juego, en la STC 24/2019 (Sala Primera), de 25 de febrero, el recurso de amparo se dirigía contra la sentencia del Juzgado de lo Penal que condenó al recurrente como autor de un delito de revelación de secretos. El recurrente consideraba que dicha condena penal ha lesionado sus derechos fundamentales a la libertad de expresión y de información [art. 20.1 a) y d) CE], en ejercicio de los cuales habría procedido a publicar una noticia que, al ser de relevancia pública y veraz, no habría vulnerado el derecho a la intimidad de la afectada, de acuerdo con lo establecido en la doctrina constitucional. Lo que las resoluciones judiciales impugnadas consideraron constitutivo del citado delito fue la conducta desplegada por el 
recurrente al incluir en la noticia difundida un extracto de movimientos de la cuenta bancaria de un tercero. Considera el TC que la información difundida tenía relevancia pública. El diario digital publicaba que la entonces presidenta de la Diputación Provincial de León, concejala del Ayuntamiento de León y, en razón del cargo público que ostentaba, miembro del Consejo de Administración de Caja España, percibía de esta entidad determinadas cantidades de dinero por los desplazamientos para asistir a las reuniones de dicho consejo pese a que los hacía en el vehículo oficial puesto a su disposición por la diputación provincial. Bajo el titular de dicha noticia y sobre la rúbrica «registro de los ingresos en la cuenta personal de la presidenta de la diputación por los inexistentes desplazamientos en vehículo particular», se incluía un extracto de cuenta bancaria con los datos de los ingresos correspondientes a dichos desplazamientos. Estima la sentencia que no ofrece duda alguna la importancia social de la noticia y de los datos asociados y publicados con ella; además, considera que el extracto bancario publicado sirve a la veracidad de la noticia. La certeza de los datos publicados es el presupuesto de la condena penal por delito de revelación de secretos por el que fue condenado el recurrente que examinamos. Su punto de partida es que el documento de extracto de movimientos bancarios difundido contiene datos supuestamente íntimos y rigurosamente ciertos. Considera el TC que la conducta del recurrente estuvo amparada por la libertad de información puesto que no se publicó ningún dato no relacionado con la noticia y los datos publicados cumplían el juicio de necesariedad en cuanto se circunscribían estrictamente a lo que se consideró «noticiable», sin que excedieran de cuanto pudiera tener relevancia informativa ni pudieran calificarse de irrelevantes, gratuitos o innecesarios. En consecuencia, la conducta del recurrente constituyó el ejercicio legítimo de su derecho fundamental a la libertad de información [art. 20.1 d) CE] de modo que la condena penal desconoció el contenido constitucional de dicho derecho fundamental.

3. En la STC 12/2019 (Sala Segunda), de 28 de enero, se aborda el recurso planteado en relación con la comisión de investigación —constituida en octubre de 2015 en las Cortes de Castilla y León- sobre distintas actuaciones del Gobierno y del Sector Público de esta comunidad autónoma. Los recurrentes en amparo, en su calidad de miembros de la comisión, solicitaron reiteradamente al presidente de este órgano el comienzo de sus trabajos, sin que se llegara a producir. Ante esta situación, en noviembre de 2017 dirigieron un escrito a la presidenta de la Asamblea en el que denunciaban la paralización de la comisión y solicitaban amparo en el ejercicio de sus funciones parlamentarias, siendo rechazada esta petición. El TC consideró que las facultades 
de creación e impulso de las comisiones de investigación forman parte del núcleo básico de la función representativa de los parlamentarios protegido constitucionalmente. Por ello, estimó que la dilación y demora en la actividad de la comisión restringió y perturbó la ejecución natural de sus tareas. En consecuencia, consideró lesionado el derecho de los recurrentes a ejercer las funciones representativas con los requisitos que señalan las leyes en conexión con el derecho de los ciudadanos a participar en los asuntos públicos a través de sus representantes.

El TC en la STC 41/2019 (Pleno), de 27 de marzo ${ }^{36}$, analizó la tramitación de la proposición que condujo a la aprobación de la Ley del Parlamento de Cataluña 19/2017, de 6 de septiembre, denominada «del referéndum de autodeterminación». En dicha tramitación, el Pleno acordó alterar el orden del día de la sesión plenaria y suprimir una serie de trámites reglamentarios con el fin de que la proposición fuese directamente sometida a debate y votación; asimismo, la Mesa acordó denegar la solicitud de dictamen del Consejo de Garantías Estatutarias sobre la concordancia de la proposición con el Estatuto de Autonomía y la Constitución, así como la solicitud de reconsideración de esta decisión. El TC, en aplicación de la doctrina contenida en las SSTC 114/2017, de 17 de octubre, y 10/2018, de 5 de febrero, declara la vulneración del derecho de los recurrentes a ejercer sus funciones representativas con los requisitos que señalan las leyes. La sentencia concluye que tanto la supresión de los trámites como la eliminación de la posibilidad de dictamen se realizaron en ausencia de previsión en el Reglamento parlamentario. Ambas resoluciones afectan a la facultad legislativa, integradora del núcleo del derecho concurrido, y correlativamente al derecho de los ciudadanos a participar en los asuntos públicos a través de sus representantes. En similares términos, la STC 42/2019, de 27 de marzo, estimó el amparo de los recurrentes en relación con la tramitación de la proposición que condujo a la aprobación de la Ley del Parlamento de Cataluńa 20/2017, de 8 de septiembre, denominada «de transitoriedad jurídica y fundacional de la República».

4. Entrando en el análisis de las resoluciones sobre el art. $24 \mathrm{CE}$, debe ser destacada la STC 1/2019 (Sala Segunda), de 14 de enero ${ }^{37}$, en la que se alegaba por el recurrente la vulneración de los derechos a la tutela judicial efectiva y a un proceso con todas las garantías. Como consecuencia de unos ejercicios militares paracaidistas, ocho de los participantes cayeron fuera de la zona seńalizada y resultaron heridos. Uno de ellos, que a consecuencia del

36 Véase supra p. 11.

37 Véase supra pp. 5 y 10. 
accidente sufrió graves lesiones, inició la vía penal para el esclarecimiento de estos hechos y su responsable. Procesado el oficial que ordenó el salto por un delito contra la eficacia del servicio, fue absuelto por el Tribunal Militar Territorial Primero. El solicitante de amparo recurrió en casación ante el Tribunal Supremo, que estimó el recurso y ordenó la celebración de nuevo juicio oral. El Tribunal Militar Territorial retrotrajo las actuaciones hasta el trámite previo de conclusiones provisionales, permitiendo de esta forma su modificación y la introducción de pruebas no propuestas anteriormente. La nueva sentencia fue igualmente absolutoria. El núcleo esencial del recurso de amparo se centraba en la alegada indefensión por parte del recurrente de que el Tribunal Militar Territorial se excedió de los límites procesales que le había impuesto la inicial sentencia del Tribunal Supremo, al haber ordenado la retroacción de las actuaciones hasta el trámite de conclusiones provisionales y permitido de este modo a la defensa rectificar su inicial propuesta de pruebas y articular una nueva proposición de las mismas, de acuerdo con las irregularidades que había advertido el Tribunal Supremo. El TC desestima el amparo aun entendiendo que la retroacción de actuaciones acordada por el Tribunal Militar Territorial pudiera ser irregular; explica el TC que no todo defecto procesal conlleva indefensión y, en consecuencia, vulneración del derecho a la tutela judicial efectiva y a un proceso con todas las garantías.

En la STC 3/2019 (Sala Segunda), de 14 de enero, el objeto del recurso era determinar si las resoluciones judiciales impugnadas habían vulnerado el derecho del recurrente a la tutela judicial efectiva (art. 24.1 CE), desde la perspectiva de la garantía de la interdicción de sometimiento a un doble proceso penal por los mismos hechos (ne bis in idem procesal), por haberse acordado su extradición a los Estados Unidos de América para ser sometido a un procedimiento penal por hechos que ya fueron objeto de enjuiciamiento en España. Recuerda el TC que la jurisprudencia constitucional ha respetado la aplicación de la garantía del ne bis in idem procesal al concreto ámbito de la cooperación judicial internacional en los supuestos en que la persona reclamada lo es por hechos que ya hubieran sido objeto de enjuiciamiento penal en España, estableciendo la imposibilidad de la entrega del reclamado para un ulterior enjuiciamiento penal en el país reclamante si un primer proceso penal ha concluido en España con una resolución de fondo con efecto de cosa juzgada. Señala la sentencia que uno de los supuestos problemáticos que ha debido abordar la jurisprudencia constitucional en el contexto de la aplicación de esta garantía procesal es el relativo a la consideración del «efecto de cosa juzgada» vinculada a las decisiones de sobreseimiento provisional y su eventual efecto preclusivo respecto de un ulterior procedimiento penal. Recuerda el TC la necesidad de ponderar los eventuales efectos de la declaración de cosa juzgada 
material de una resolución judicial de sobreseimiento — con independencia de su carácter definitivo o provisional-, atendiendo a las circunstancias del caso concreto. Las resoluciones judiciales impugnadas traían causa de la solicitud, por parte de las autoridades de los Estados Unidos, de la entrega del recurrente para su enjuiciamiento en relación, entre otros, con su eventual participación en los hechos que dieron lugar a la aprehensión de importantes cantidades de estupefacientes; por un lado, en relación con la aprehensión de la nave Pandora. En este caso, si bien el recurrente fue un sospechoso policial, no llegó a dictarse ningún tipo de imputación judicial contra el mismo; sin embargo, en relación con la aprehensión de la nave Adamas, el Juzgado Central de Instrucción incoó diligencias previas, el recurrente fue objeto de una medida cautelar de prisión preventiva y se dictó contra él auto de procesamiento, pero la Audiencia Nacional acordó el sobreseimiento provisional de las actuaciones respecto del recurrente de amparo. Las resoluciones judiciales impugnadas denegaron que concurriera la causa obligatoria de denegación de la extradición de que «la persona reclamada sea objeto de un proceso o haya sido ya juzgada y absuelta en el territorio de la parte requerida por el delito por el cual se pide la extradición», con el argumento de que nunca fue enjuiciado en España por estos hechos, ya que, en el primer caso, nunca pasó a la situación de investigado judicial y, en el segundo, la causa fue sobreseída provisionalmente respecto de su eventual participación en los hechos enjuiciados sin llegar a ser formalmente acusado. En atención a la jurisprudencia constitucional, la sentencia considera que las resoluciones judiciales impugnadas no han vulnerado el derecho a la tutela judicial efectiva del recurrente, desde la perspectiva de la interdicción de sometimiento a doble enjuiciamiento penal, con la decisión de entrega para un eventual enjuiciamiento en los Estados Unidos en relación con los hechos derivados de la aprehensión del velero Pandora, toda vez que esos hechos no dieron lugar a proceso judicial español y el recurrente nunca se ha visto sometido a un procedimiento penal en Espańa con la carga y gravosidad que ello implica. Sin embargo, estima que las resoluciones judiciales impugnadas vulneraron el derecho a la tutela judicial efectiva del recurrente, desde la perspectiva de la interdicción de sometimiento a doble enjuiciamiento penal, con la decisión de entrega para un eventual enjuiciamiento en los Estados Unidos en relación con los hechos derivados de la aprehensión del velero Adamas toda vez que, por esos hechos, fue dirigido singularmente contra el recurrente durante toda la fase de instrucción, llegando a ser objeto de una medida cautelar de prisión provisional y manteniéndose como imputado en el auto de conclusión del sumario. Concluye el TC considerando que la afirmación de las resoluciones judiciales impugnadas de que resultaba suficiente para rechazar la invocación del ne bis in idem procesal 
la mera constatación de que el auto de sobreseimiento era provisional y no definitivo, sin valorar las concretas circunstancias en que fue adoptada la decisión, es contraria a la garantía de la interdicción de doble enjuiciamiento penal en el ámbito transnacional, que forma parte del derecho a la tutela judicial efectiva.

En la STC 10/2019 (Sala Segunda), de 28 de enero, los recurrentes en amparo interpusieron una querella ante la Audiencia Nacional contra el expresidente de la República Popular China, Jiang Zemin, por los posibles delitos de genocidio y torturas sufridos por los miembros del movimiento espiritual Falun Gong. Este procedimiento fue declarado concluso por falta de jurisdicción, decisión recurrida en amparo y estimado por STC 227/2007, ordenándose la reapertura del procedimiento. Posteriormente, la Ley Orgánica 1/2014, de 13 de marzo, de modificación de la Ley Orgánica 6/1985, de 1 de julio, del Poder Judicial, relativa a la justicia universal, introdujo nuevos puntos de conexión como requisitos para la jurisdicción universal y la disposición transitoria ordenó el sobreseimiento de aquellos procedimientos abiertos hasta que no se acreditara el cumplimiento de tales requisitos. En aplicación de esta disposición, el procedimiento fue archivado. El TC desestima el recurso de amparo en aplicación de su doctrina contenida en la STC 140/2018, de 20 de diciembre, que se pronunció sobre la constitucionalidad de la regulación antes citada. La sentencia declara que no ha sido vulnerado el derecho de los recurrentes a la tutela judicial efectiva en relación con el acceso a la jurisdicción, ya que los tribunales no se apartaron de la doctrina del TC en la STC 227/2007, de 22 de octubre, al archivar el procedimiento tras la promulgación de la modificación porque estos cambios introdujeron unos requisitos legales distintos que debían ser aplicados; por otra parte, estimó que la disposición no contraviene el principio de irretroactividad de las disposiciones sancionadoras o restrictivas de derechos, ya que la STC 140/2018, de 20 de diciembre, declaró que esta disposición no restringía el derecho a la tutela judicial efectiva. En similares términos, las SSTC 23/2019, de 25 de febrero, 35 y 36, de 25 de marzo de 2019.

El principio de primacía del derecho de la Unión Europea ha sido analizado en la STC 31/2019 (Pleno), de 28 de febrero ${ }^{38}$. En el marco de un procedimiento de ejecución hipotecaria, un juzgado de primera instancia inadmitió el incidente de nulidad promovido por la recurrente en el que denunciaba el carácter abusivo de una cláusula de vencimiento anticipado incorporada en su contrato de préstamo con garantía hipotecaria. El incidente fue promovido por la recurrente tras haber el juzgado despachado ejecución y una vez precluido el

38 Véanse supra pp. 229 y 233-234. 
plazo legal para la oposición a la ejecución, encontrándose aún pendiente el lanzamiento de la recurrente. El TC estima el recurso de amparo, entendiendo que debió aplicarse la jurisprudencia del Tribunal de Justicia de la Unión Europea (TJUE) [sentencia de 26 de enero de 2017, Banco Primus y Jesús Gutiérrez García, (Banco Primus)], en la que se afirmaba que el juez nacional en cualquier momento del procedimiento debe controlar de oficio el posible carácter abusivo de las cláusulas contractuales, con la única excepción de que la cláusula denunciada hubiera sido examinada previamente. El TC reprocha al órgano judicial el incumplimiento del principio de primacía del derecho de la Unión Europea al haber omitido el control previo de la cláusula abusiva alegada, al que el Juzgado de Primera Instancia se encontraba obligado por lo manifestado por el TJUE en el asunto Banco Primus. Por tanto, el TC concluye que la decisión impugnada ha vulnerado el derecho a la tutela judicial efectiva de la recurrente al ofrecer a la demandante de amparo una respuesta inmotivada acerca de la existencia de un control de la cláusula previo a la denuncia, que es la única excepción contemplada por el Tribunal de Justicia para excluir un examen posterior. La sentencia cuenta con un voto particular discrepante del magistrado Enríquez Sancho.

En la STC 37/2019 (Pleno), de 26 de marzo ${ }^{39}$, el TC estimó el recurso de amparo planteado por la Administración General del Estado contra la sentencia dictada por el Tribunal Supremo; la Administración recurrente en amparo se quejaba de que el órgano judicial ha inaplicado el art. 45.4 LSE entonces en vigor, que establece el régimen de financiación del bono social eléctrico, al considerar que es incompatible con el art. 3.2 de la Directiva 2009/72/CE, adoptando esa decisión sin previamente plantear cuestión prejudicial ante el TJUE, ofreciendo una motivación manifiestamente insuficiente para justificar ese proceder, pues alegó que resultaba aplicable la doctrina sobre el «acto aclarado", con base en las sentencias recaídas en los asuntos Federutility y Anode, pero sin argumentar de manera suficiente tal decisión. Además, para la Administración no había identidad material entre los casos ya resueltos por el TJUE y el que se enjuicia en la sentencia impugnada, sin que tampoco los supuestos cotejados sean análogos. El TC aborda, desde la perspectiva propia del derecho a un proceso con todas las garantías (art. 24.2 CE), la queja relativa a la inaplicación de la norma nacional sin necesidad de plantear cuestión prejudicial ante el TJUE. Entiende el TC que en el procedimiento a quo no concurrían los presupuestos necesarios para apreciar que la doctrina emanada en las referidas sentencias del TJUE constituía un «acto aclarado» respecto del problema interpretativo suscitado $y$, por tanto, el órgano judicial no estaba

39 Véanse supra pp. 13-14. 
dispensado de plantear cuestión prejudicial ante el mencionado Tribunal de Justicia. Así pues, se afirma que se ha lesionado el derecho a un proceso con todas las garantías, toda vez que el órgano judicial ha inaplicado la normativa nacional por considerarla incompatible con el art. 3.2 de la Directiva 2009/72/ $\mathrm{CE}$, sin previamente recabar un pronunciamiento prejudicial del TJUE. Ello ha dado lugar a una preterición del sistema de fuentes, con desconocimiento de las garantías que integran el proceso debido. La sentencia cuenta con un voto particular discrepante del magistrado Ollero Tassara.

En la STC 47/2019 (Sala Segunda), de 8 de abril, se otorga el amparo a una empresa que, en el curso de un proceso judicial, fue emplazada y citada como demandada para el acto de conciliación y juicio a través de su dirección electrónica habilitada. Al utilizar ese medio de notificación, la empresa no accedió a dicha comunicación y al no tener conocimiento de la misma, no compareció. Como consecuencia, fue tenida como confesa en el procedimiento y este fue resuelto en favor de la demandante. El TC consideró lesionado el derecho a la tutela judicial efectiva sin indefensión; entiende la sentencia que, si bien la realización de actos de comunicación a través de la dirección electrónica habilitada constituye la vía de comunicación bidireccional ordinaria entre la Administración de Justicia y las personas y entidades obligadas a utilizar estos medios electrónicos — como era el caso de la empresa por ser una persona jurídica-, los preceptos legales de aplicación establecen un régimen especial para los primeros actos de comunicación (emplazamiento y citación). Así, estos actos de comunicación han de ser realizados por correo certificado con acuse de recibo en el domicilio del destinatario. Recuerda el TC su doctrina de la reciente STC 6/2019, de 17 de enero, en la que afirmó que como excepción no se ha de llevar a cabo por medios electrónicos la comunicación al demandado aún no personado en el procedimiento, en cuanto al acto de citación o emplazamiento, conforme a lo previsto en el art. 155.1 LEC, los cuales «se harán por remisión al domicilio de los litigantes», regla que también opera en el proceso laboral (art. 53.1 LJS). En el caso analizado, concluye el TC, el modo en que se efectuó la primera comunicación con la demandante de amparo no es el que establecen los arts. 56.1 LJS y 155.1 y 2 . LEC y, por consiguiente, el hecho de que aquella no hubiera accedido al contenido de la comunicación, en el plazo señalado en el art. 162.2 LEC, no puede ser considerado un factor determinante de la falta de celo o del comportamiento omiso que se alega, ni capaz, por ende, de enervar la indefensión de la que se queja la recurrente.

La cuestión planteada en la STC 49/2019 (Sala Segunda), de 8 de abril, era si el decreto de la letrada de la Administración de Justicia — que declaró los honorarios reclamados por el abogado recurrente en amparo como 
indebidos - podía ser o no objeto de recurso de revisión ante el juzgado que resolvió el litigio del que dichos honorarios traían causa, considerando la demanda que las diversas resoluciones dictadas, tanto por la letrada de la Administración de Justicia como después por la juzgadora, lesionaron su derecho fundamental a la tutela judicial efectiva al impedir la revisión jurisdiccional por el cauce del recurso de revisión que formuló. Con remisión a lo dicho por el TC en las SSTC 58/2016, de 17 de marzo, y 72/2018, de 21 de junio, y 34/2019, de 14 de marzo, considera que la exclusión de recurso frente al decreto priva del acceso al control jurisdiccional de una decisión adoptada en el seno de un proceso por un órgano no investido de función jurisdiccional y da lugar al inicio del procedimiento de ejecución, prescindiendo de ese control y excluyendo a la parte de la posibilidad de impugnación contra la decisión del letrado de la Administración de Justicia. Considera el TC que el régimen de recursos establecido contra los decretos de los letrados de la Administración de Justicia en las reclamaciones de honorarios de abogados impedía, entonces, que las decisiones de estos letrados fueran revisadas por los jueces y tribunales, titulares en exclusiva de la potestad jurisdiccional (art. 117.3 CE), vedando, por consiguiente, que pudieran dispensar la tutela judicial efectiva sin indefensión que garantiza el art. 24.1 CE. Recuerda que la STC 34/2019, de 14 de marzo, se fundó en la existencia de un espacio de inmunidad jurisdiccional incompatible con las exigencias del derecho a la tutela judicial efectiva, que priva a las partes, dada la ausencia de recurso contra el decreto del letrado de la Administración de Justicia, de instrumentos indispensables para la defensa de sus derechos e intereses legítimos, como ocurre con su derecho a que dicha decisión procesal sea examinada y revisada por quien está investido de jurisdicción (esto es, por el juez o tribunal), por lo que se declaró la inconstitucionalidad y nulidad "del párrafo tercero del art. 34.2 y del inciso "y tercero" del párrafo segundo y del párrafo cuarto del art. 35.2 de la Ley 1/2000, de 7 de enero, de enjuiciamiento civil, en la redacción dada por la Ley 13/2009, de 3 de noviembre, de reforma de la legislación procesal para la implantación de la nueva oficina judicial», en cuanto que determinaban la ausencia de recurso frente al decreto del letrado de la Administración de Justicia en la materia controvertida.

Por último, simplemente debe darse cuenta de la STC 29/2019 (Pleno), de 28 de febrero ${ }^{40}$, en la que se abordó el recurso planteado por el entonces presidente de la Asamblea Nacional Catalana, que, como consecuencia de las concentraciones y manifestaciones llevadas a cabo los días 20 y 21 de septiembre de 2017 en Barcelona, fue encausado por presuntos delitos de sedición e

40 Véase supra p. 230. 
ingresado en prisión provisional. La queja principal se refería a la privación de libertad y la vulneración, por tanto, del art. 17 CE. Afirma el TC que la resolución judicial satisface el canon de motivación reforzada exigido por el derecho a la libertad personal: el tipo de delito y la gravedad de la pena son datos suficientes y razonables para inferir un riesgo notable de fuga del recurrente. En similares términos la STC 30/2019 (Pleno), de 28 de febrero ${ }^{41}$.

41 Carlos Ortega Carballo. 